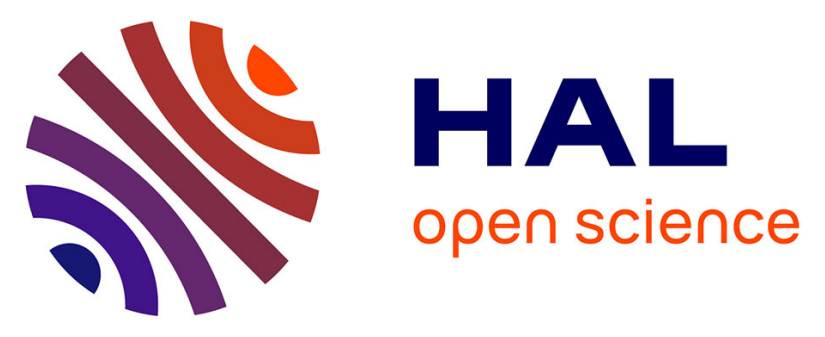

\title{
Near IR Nonlinear Absorbing Chromophores with Optical Limiting Properties at Telecommunication Wavelengths
}

Pierre-Antoine Bouit, Guillaume Wetzel, Gérard Berginc, Brigitte Loiseaux, Loic Toupet, Patrick Feneyrou, Yann Bretonnière, Kenji Kamada, Olivier Maury, Chantal Andraud

\section{To cite this version:}

Pierre-Antoine Bouit, Guillaume Wetzel, Gérard Berginc, Brigitte Loiseaux, Loic Toupet, et al.. Near IR Nonlinear Absorbing Chromophores with Optical Limiting Properties at Telecommunication Wavelengths. Chemistry of Materials, 2007, 19 (22), pp.5325-5335. 10.1021/cm071557h . hal-01320790

\section{HAL Id: hal-01320790 \\ https://hal.science/hal-01320790}

Submitted on 21 Nov 2017

HAL is a multi-disciplinary open access archive for the deposit and dissemination of scientific research documents, whether they are published or not. The documents may come from teaching and research institutions in France or abroad, or from public or private research centers.
L'archive ouverte pluridisciplinaire HAL, est destinée au dépôt et à la diffusion de documents scientifiques de niveau recherche, publiés ou non, émanant des établissements d'enseignement et de recherche français ou étrangers, des laboratoires publics ou privés. 


\section{Near IR Nonlinear Absorbing Chromophores with Optical Limiting Properties at Telecommunication Wavelengths}

Pierre-Antoine Bouit, ${ }^{\dagger}$ Guillaume Wetzel, ${ }^{\ddagger}$ Gérard Berginc, ${ }^{\perp}$ Brigitte Loiseaux, ${ }^{\ddagger}$ Loïc Toupet, ${ }^{\#}$ Patrick Feneyrou, ${ }^{\dagger}$ Yann Bretonnière, ${ }^{\dagger}$ Kenji Kamada, ${ }^{\approx}$ Olivier Maury, ${ }^{* \dagger}$ Chantal Andraud. ${ }^{* \dagger}$

${ }^{\dagger}$ Laboratoire de Chimie, UMR 5182- ENS-Lyon, 46 Allée d'Italie, F-69364 Lyon cedex 07, France, chantal.andraud@ens-lyon.fr

¥Thales Research \& Technology France, Route Départementale 128, 91767 Palaiseau Cedex, France ; patrick.feneyrou@thalesgroup.com

${ }^{\perp}$ Thales Optronique SA, BP 55, Rue Guynemer, 78283 Guyancourt, France

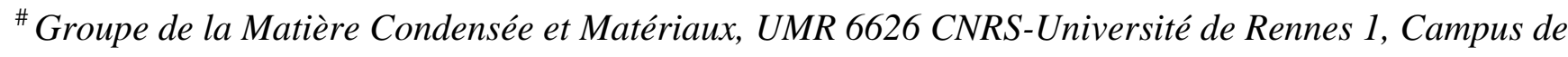
Beaulieu, 35042 Rennes cedex, France

$\approx$ Photonics Research Institute, National Institute of Advanced Industrial, Science and Technology (AIST), AIST Kansai Center, 1-8-31 Midorigaoka, Ikeda, Osaka 563-8577, Japan, k.kamada@aist.go.jp 


\begin{abstract}
Dipolar and symmetrical heptamethine dyes featuring strong linear absorption in the near infra-red spectral range $(700-900 \mathrm{~nm})$ were prepared at a gram scale. X-ray crystallographic structure of the dipolar chromophore is described revealing the remarkable planarity of the polyenic chain due to the central ring of the molecule. These chromophores present promising nonlinear absorption properties at telecommunication wavelengths (1400-1600 nm): (i) significant two-photon cross section were measured using femtosecond Z-scan method and (ii) their exceptional solubility allows carrying optical limiting experiment at $1500 \mathrm{~nm}$ in nanosecond regime. In this regime, experimental data were interpreted on the basis of two photon absorption (2PA) and 2PA induced excited state absorption (ESA). Finally, these systems, which present a lot of relevant properties (significant nonlinear absorption properties, two-step gram scale synthesis, high solubility, good thermal stability and several sites of functionalization), open the way to numerous practical applications in biology, solid state optical limiting and signal processing.
\end{abstract}




\section{Introduction}

Materials displaying multiphotonic absorption properties have been extensively studied for applications in the field of material science (optical storage, optical limitation, microfabrication) or in biology (imaging, drug delivery, photodynamic therapy) generally using fs-pulsed laser source emitting in the visible range (400-900 nm). ${ }^{1}$ The rapid development of frequency-tuneable pulsed laser up to telecommunication wavelengths $(1400-1600 \mathrm{~nm})$ prompted the scientific community to the design of new materials for nonlinear absorption in the near infra-red region (NIR). In this spectral range, such materials could address various applications for optical limiting (OL), such as gain equalization of Erbium amplifier for telecommunication systems, protection of monostatic LIDAR (light detection and ranging) detectors against intense retro-reflection / backscattering (in addition to or replacement of detector gating) and protection of active imagery systems against laser threat. A good OL device should be able to protect optical sensors like eyes or camera against damages caused by high-energy laser illumination: it has to be transparent in the spectral range of the detector as long as the light intensity remains below the sensor safety threshold and instantaneously attenuate the beam when its intensity exceeds this threshold. ${ }^{2}$ Most of the OL studies reported to date deal with laser emitting in the visible range $(400-1000 \mathrm{~nm})$, where the nonlinear transmission phenomena are mainly based on multiphotonic absorption, reverse saturable absorption or nonlinear scattering and the materials designed for such purpose are generally organic molecules e.g. fullerene, carbon nanotube, (oligo)-fluorene based chromophores, metallo-porphyrines or phtalocyanines and organometallic complexes. ${ }^{2 \mathrm{~d}, 3}$ It is important to note that the NIR spectral region has been less investigated. To date inorganic semiconductors are known to present a significant two-photon absorption (2PA) coefficient $\left(\alpha_{2}\right)$ of $1.910^{-10} \mathrm{~m} . \mathrm{W}^{-1}$ at 1300 $\mathrm{nm} ;{ }^{4}$ as far as organic systems are concerned, only a few works were reported: Marder and coworkers reported bis-dioxaborine polymethines based materials with large microscopic and macroscopic third order nonlinearities at $1300 \mathrm{~nm}$, dipolar chromophores with a 2PA response in the NIR wavelengths range $^{5}$ and extended conjugated quadrupolar chromophores with strong 2PA properties centered around $1000 \mathrm{~nm},{ }^{6}$ but with additional properties at telecommunications wavelengths. ${ }^{7}$ In the same context, 
fused azulene and oligomeric porphyrins were also shown to exhibit large 2PA cross-sections between 1200-1400 nm, ${ }^{8}$ while singlet diradical compounds ${ }^{9}$ and nickel bis(diothiolene) complexes exhibit properties at telecommunications wavelengths ${ }^{10}$. On the other hand the group of Prasad, recently described OL measurements at $1300 \mathrm{~nm}$ based on three-photon absorption properties using linear or multi-branched chromophores, with a maximal nonlinear transmittance of nearly $0.7 .{ }^{11}$ Finally, OL by reverse saturable absorption was observed at $1315 \mathrm{~nm}$ in fullerene doped polyimides. ${ }^{12}$

The observation of an efficient $2 \mathrm{PA}$ process at the wavelength $\lambda$ requires the design of chromophores with a linear absorption at least at higher wavelength than $\lambda / 2$. In the present case for 2PA in the 1400-1600 $\mathrm{nm}$ range, target chromophores have to present an intense linear absorption at wavelengths larger than 700-800 nm. Furthermore, to be used for practical applications, an additional set of specific conditions must be fulfilled (i) a large solubility in organic solvents, (ii) a good thermal and photophysical stability and (iii) a synthesis achieved at a gram scale, which is a real challenge for highly conjugated molecules. For that purpose, we focused on symmetrical heptamethine chromophores ${ }^{13}$ largely used in biological imaging applications for their particular absorption in the near IR (700-900 nm) $)^{14}$ and on new dipolar related compounds. Target dyes 1-6 (scheme 1) present a polyenic backbone locked in a cyclohexyl ring to increase the photostability; in addition all the compounds are functionalized by hexyl or benzyl fragments to increase their solubility and by a lateral bulky tert-butyl group to prevent aggregation. Keeping in mind further practical applications, the preparation of dyes 1-6 requires only a few steps and the synthesis can be achieved on a gram scale. In this article, we report on the synthesis and chemical characterization of these six dyes; the X-rays structure of a new dipolar chromophore is also depicted. 2PA properties of these dyes in the NIR spectral range (1300-1600 nm) were determined using Z-scan technique in the femtosecond regime, and optical limiting studies were performed in the nanosecond regime. It is also worth noting that this paper described the first optical limiting properties of organic dyes at the telecommunications wavelength of $1500 \mathrm{~nm}$, which is of prime importance for further practical applications. 


\section{Results and discussion.}

Synthesis and characterization. The tert-butyl functionalized chloro-bis-aldehyde $\mathbf{A}^{15}$ is the common starting material for the synthesis of chromophores 1-6. The heptamethine dyes 1-4 were classically prepared on a gram scale by condensation of $\mathbf{A}$ with benzothiazolium or indolenium salts under mild experimental conditions. ${ }^{16}$ Whereas condensation of $\mathbf{A}$ with two equivalents of indolenium salt gave the expected $2 / 1$ adduct as the only product, reaction with benzothiazolium salts mainly led to the formation of a $3 / 1$ adduct. This new product results from the substitution of the lateral chloride atom by 2-hydroxyl-benzothiazole formed in situ by addition to the starting salt of a water molecule liberated during the first condensation. ${ }^{17}$ This $3 / 1$ adduct is the once product formed in the presence of an excess of benzothiazolium salt and was isolated in good yield. On the other hand, the dipolar chromophores 5-6 were obtained in a one-pot two-steps procedure by successive additions of tricyanofurane and indolenium salt to $\mathbf{A}$ using more drastic experimental conditions (scheme 1$) \cdot{ }^{18}$ It is worth noting that both dipolar chromophores are chiral, the carbon carrying the ${ }^{\mathrm{t}} \mathrm{Bu}$ fragment, noted $\mathrm{C} 4$ on the ORTEP drawing (vide supra) is asymmetric, but only racemic mixtures were considered. All these compounds (1-6) are very soluble in all common organic solvents and were isolated as green microcrystalline powder in good to moderate yields after recrystallization or column chromatography. Complete characterization is provided in the experimental section: ${ }^{1} \mathrm{H}$ NMR spectra of 3-4 (Figure 1) exhibit only two signals (doublet) for the vinylic proton indicating a $C_{2 v}$ symmetric architecture of the molecule with a complete delocalization of the cationic charge over the $\pi$-conjugated backbone. These signals are slightly modified for compounds 1-2; each doublet is divided in two, the hindered free rotation of the lateral bulky benzothiazole substituent breaking the $C_{2 v}$ symmetry. Finally, the polyenic chain of the dipolar compounds 5-6 presents two different sets of signals in agreement with an asymmetric structure. It is worth noting that, in all cases the vinylic ${ }^{3} J_{H-H}$ coupling constant, comprised between 13 and $16 \mathrm{~Hz}$, unambiguously indicates the all trans configuration of the $\mathrm{sp}^{2}$ carbon squeleton. All compounds are thermally robust with $10 \%$ weight loss decomposition temperature comprised between 210 and $280^{\circ} \mathrm{C}$ 
(Table 1), which is of prime importance for further applications. It is worth noting that benzothiazole derivatives 1-2, exhibiting the lowest decomposition temperature, also present the lowest chemical stability. ${ }^{19}$

X-rays crystal structure. Single crystals of $\mathbf{6}$ were obtained as thin needles, featuring metallic shine by slow evaporation of a toluene/chloroform mixture. Crystal data and refinement parameters are summarized in the experimental section. The dipolar chromophore crystallizes in a centrosymmetric space group and the crystal packing is composed of a stacking of linear chains of dimers (Figure 2a). The elementary dimeric unit is composed by the two different enantiomers, that can be distinguished by the blue and red colors in Figures 2a,b, and which are organized in a head-to-tail way. The intermolecular interaction seems to be driven by the steric repulsion ensured by the benzyl and tertbutyl fragment resulting in a closed packing between two cyano functions of the tricyanofurane acceptor group $(\mathrm{d} \approx 3.1-3.2 \AA)$. The intra-chain cohesion is ensured by hydrogen bonds between the cyano acceptor fragment and a benzenic proton of a donor group inducing a D-A $\cdots$ D-A intra-chain organization. Finally, the interchains interactions (with the green molecule in Figure 2a,b) originates from $\mathrm{C}-\mathrm{H}$...Cl interactions $(\mathrm{d}=2.9 \AA)$ between the methyl fragment of the dimethylindole moieties and the chloride atom resulting in a quasi-orthogonal arrangement of two neighboring chains (Figure 2b). On the molecular scale, the ORTEP drawing (Figure 2c for one enantiomer) reveals a perfectly planar structure without any significant twist of the polyenic chain, the overall tilt angle between the phenyl donor and the tricyanofurane acceptor plane being only about $10^{\circ}$. This remarkable planarity is mainly due to the presence of the central six members ring containing three $\mathrm{sp}^{2}$ carbon atoms, whose conformation is further constrained by the most stable equatorial position of the tert-butyl fragment. The all trans twelve $\mathrm{sp}^{2}$ carbons backbone, linking the amino donor to the cyano acceptor groups, presents a very regular alternance of single and double bonds, whose average lengths are 1.425 and $1.364 \AA$ respectively. ${ }^{20}$ These classical values confirm the strong dipolar character of the molecule with a complete delocalization over the extended $\pi$-conjugated skeleton. 
Linear and nonlinear optical properties. Absorption spectra of 1-4 in dichloromethane solution (Figure 3 and Table 1) are characteristic of cyanine-like derivatives ${ }^{10,21}$ i.e. a sharp electronic transition in the NIR region with huge extinction coefficient $\left(\lambda \max (3)=791 \mathrm{~nm}, \varepsilon=355000 \mathrm{~L}_{\mathrm{Mol}} \mathrm{Mol}^{-1} \cdot \mathrm{cm}^{-1}\right)$ and a less intense shoulder at higher energy. As already described, chromophores featuring the stronger benzothiazole donating group $(\mathbf{1}, \mathbf{2})$, present the most red-shifted absorption wavelength $\left(\lambda_{\max }(\mathbf{1})=825\right.$ nm and $\left.\lambda_{\max }(2)=833 \mathrm{~nm}\right),{ }^{13}$ while dipolar compounds 5-6 exhibit a broad absorption band in the 600$900 \mathrm{~nm}$ range resulting from the overlap of both transitions. ${ }^{22}$ It is important to note that the shape of these spectra remains unchanged when the concentration varies from $10^{-7}$ to $10^{-4}$ mol. $\mathrm{L}^{-1}$, and follows the Beer-Lambert law. This observation excludes the possibility of aggregation effects within this concentration range and can be connected to the presence of the bulky ${ }^{t} \mathrm{Bu}$ fragment in the central part of the molecule and the benzyl- or alkyl-amine functionality. ${ }^{10 b, 23}$

Two-photon absorption spectra were measured by using an open aperture Z-scan method between 1200 and $1600 \mathrm{~nm}$ with a fs-optical parametric amplifier pumped by a Ti:sapphire regenerative amplifier laser operating at $1 \mathrm{kHz}$ as a light source. Typical pulse duration was $130 \mathrm{fs}$. Details of the setup were published previously. ${ }^{24}$ At each wavelength, the open-aperture traces were recorded by changing the incident power of the laser beam form 0.1 to $0.7 \mathrm{~mW}$ corresponding to the on-axis peak intensity at the focal point $I_{0}$ of $7 \sim 80 \mathrm{GW} \mathrm{cm}^{-2}$ depending on the Rayleigh range $\left(z_{\mathrm{R}}=11 \sim 14 \mathrm{~mm}\right)$. The sample solutions in spectroscopic grade dichloromethane $\left(4 \sim 5 \mathrm{~mol} . \mathrm{L}^{-1}\right)$ poured in a 1-mm quartz cuvette were used for the measurements. The longer $z_{\mathrm{R}}$ than the length of the sample $(L=1 \mathrm{~mm})$ fulfills the optically-thin condition. ${ }^{25}$

The basic theory for the analysis of the open-aperture Z-scan and the nonlinear transmittance measurements are the same. When a material absorbs light by only 1PA and 2PA processes and the cascading processes can be ignored, the transmission of the sample can be computed using the following equation (1):

$$
\frac{d I}{d z}=-\alpha_{1} I-\alpha_{2} I^{2}
$$


where $I$ is the optical intensity, $z$ is the propagation axis $\square$ coordinate and $\alpha_{1}$ and $\alpha_{2}$ are the 1PA (linear) and 2PA absorption coefficients, respectively. Under the current experimental conditions, all solutions were transparent at the operating wavelengths $\left(\alpha_{1} \approx 0 \mathrm{~cm}^{-1}\right)$. Thus, the term including $\alpha_{1}$ can be ignored and the equation (1) become simplified as $\frac{d I}{d z}=-\alpha_{2} I^{2}$. Considering the propagation of a collimated laser beam with a Gaussian distribution in time and space through a media having only 2PA, the nonlinear transmittance $T_{n l}$ can be expressed by equation (2), ${ }^{26}$

$$
T_{n l}=\frac{1}{\sqrt{\pi} \alpha_{2} L I} \int_{-\infty}^{\infty} \ln \left(1+\alpha_{2} L I e^{-u^{2}}\right) d u(2)
$$

For the nonlinear transmittance measurements this relation can be used as it is because $I$ is the control parameter. Meanwhile, for the Z-scan experiments, $T_{n l}$ is a function of a sample position $z$ because $I$ is now a function of $z$ as $I(z)=\frac{I_{0}}{1+\left(z / z_{R}\right)^{2}}$. By the curve fit with these relations to the recorded openaperture traces, the value of $\alpha_{2}$ was obtained. At some wavelength in the NIR region, the solvent has overtone of vibrational absorption. At such a wavelength, the depression of the incident power by the overtone was taken into account by replacing $L$ in the equation (2) with the effective path length $L_{\text {eff }}=\frac{1-e^{-\alpha_{1} L}}{\alpha_{1}}$, where the 1PA coefficient of the solvent is used for $\alpha_{1}$. The $\alpha_{2}$ value obtained by this procedure did not change for the different values of $I_{0}$ employed, which guarantees that the $\alpha_{2}$ obtained by the femtosecond Z-scan measurements contains negligible contribution by higher-order processes $^{27}$ such as the effective three-photon absorption, i.e. 2PA-induced excited state absorption (ESA). Finally, 2PA cross section $\sigma_{2 P A}$ is calculated from the convention:

$$
\sigma_{2 P A}=\frac{h v}{N} \alpha_{2}
$$

where $N$ is the number density of molecules and $h v$ is the photon energy at the operating wavelength. 
Figure 4 shows the comparison of 2PA and 1PA spectra of compounds 2, 4 and $\mathbf{6}$ that present all significant 2PA absorption in the 1300-1500 nm range. The 2PA spectrum of the non centrosymmetric dipolar compound (6) matches the wavelength-doubled scale 1PA absorption (Figure 4c). The case of the polymethine cyanines 2 and $\mathbf{4}$ (Figure 4a,b) is different; the 2PA spectrum is blue shifted with respect to the wavelength doubled main transition of the 1PA spectrum, and seems to match the weakest band. It is well known that the selection rules for centrosymmetric molecules is complementary for 1PA and 2PA transitions: a 1PA-allowed transition is forbidden for 2PA transition and vice versa. ${ }^{28}$ It is not clear to date why the 2PA peak overlaps with the weakest 1PA band, i.e. coincidence in the transition energies to $1 \mathrm{PA}$ - and 2PA-allowed excited states, or breaking of the centrosymmetry due to vibronic coupling or other reasons. Theoretical calculations are currently in progress for the assignment of these different transitions. All compounds present maximal 2PA wavelength $\lambda^{(2)}$ between 1430-1500 $\mathrm{nm}$, and interestingly $\mathbf{2}$, which presents the most red-shifted 1PA wavelength, exhibits also the most redshifted 2PA wavelength. The maximum two photon cross-sections $\sigma_{2 P A}^{\max }$ summarized in Table 1 are comprised between 450-800 GM. The $\sigma_{2 P A}^{\max }$ values obtained in the case of polymethine dyes $\mathbf{2}, \mathbf{4}$ compare well with that of related compounds briefly described in the literature. ${ }^{29}$ The $\sigma_{2 P A}^{\max }$ of the dipolar chromophore 6, is slightly higher $\left(\sigma_{2 P A}^{\max }=792+/-74 \mathrm{GM}\right.$ at $\left.1445 \mathrm{~nm}\right)$ but remains lower than those reported for other dipolar compounds featuring a longer $\pi$-conjugated backbone $\left(\sigma_{2 P A}^{\max }=1500\right.$ $\mathrm{GM}$ at $1440 \mathrm{~nm})^{5 \mathrm{~b}}$ or for the related squarine $\left(\sigma_{2 P A}^{\max }=2100 \mathrm{GM}\right.$ at $\left.1300 \mathrm{~nm}\right) .^{6}$

Optical limiting performance and the mechanism. The high solubility of these compounds allows performing optical limiting experiment in the NIR spectral range. Nonlinear transmittance measurements were carried out in the 1200-1600 nm range using a tripled Q-switched Nd:YAG laser pumping an optical parametric oscillator $(7 \mathrm{~ns}$ pulse, $10 \mathrm{~Hz}$ ) focused in a $2 \mathrm{~mm}$ Quartz cell. Typical beam waist $\omega_{0} \approx 60 \mu \mathrm{m}$ is chosen in order to get high incident energy densities in the sample, while achieving a Rayleigh range higher than the $2 \mathrm{~mm}$ thickness of the cells and minimizing the influence of thermal defocusing effects (see experimental section). The sample is a micro-filtrated dichloromethane 
solution of 1-6 at high concentration (100-350 g.L $\left.\mathrm{L}^{-1}\right)$. For all samples, variations of the nonlinear transmittance $v s$. the incident laser energy at a given wavelength present the characteristic behavior of an optical limiter: a good transmission at low energy $(\mathrm{T}>0.9)$ that significantly decreases at higher energy. A representative example is described in Figure 5, in the case of a concentrated solution of $\mathbf{1}$ using $1500 \mathrm{~nm}$ as fundamental incident wavelength. This is, to our knowledge, the first OL curve at telecommunications wavelength reported in literature for organic molecules; similar curves were obtained for each molecule 1-6. Experimental points were limited due to the weak power of the incident laser, but an attenuation of $40 \%$ of the incident laser beam (incident energy $3.10^{-4} \mathrm{~J}$ ) can be reached (Figure 5). The relevant role of the concentration on nonlinear transmission properties was studied in the case of 1 at $1500 \mathrm{~nm}$. Upon decreasing the sample concentration from 0.33 to $0.23 \mathrm{~mol} . \mathrm{L}^{-1}$, a significant flattening of the nonlinear transmission is observed (Figure 5). It must be noted that experimental concentrations used for the OL experiment (Table 2) were not maximal and that more efficient transmission attenuation could be readily reached.

As the theoretical treatments for the open-aperture Z-scan and the nonlinear transmittance measurements are the same as mentioned above, the obtained OL curve was first analyzed with the equation (2) assuming that the only 2PA process is involved in the observation. The simulation curves considering only 2PA process (blue curves of Figure 6), with the two-photon absorption coefficient $\alpha_{2}^{\text {calcd }}$ calculated according to (3) using the $\sigma_{2} \mathrm{PA}$ value determined from the fs Z-scan experiments and with the concentrations of the OL samples, exhibit large deviation from the observed data. Such a large difference was already observed in the nanosecond regime. ${ }^{30}$ When the pulse duration is comparable or longer than the lifetime of the excited state of the molecule, high-order phenomena like 2PA-induced ESA become non negligible. The higher-order effect must be taken into account as eq. (4):

$$
\frac{d I}{d z}=-\alpha_{1} I-\alpha_{2} I^{2}-\alpha_{3} I^{3}
$$

where $\alpha_{3}$ is the three-photon absorption (3PA) coefficient. Any nonlinear absorption process with the same order as 3PA is included in $\alpha_{3}$, thus the 2PA-induced ESA process is included in it. The OL curves 
were fitted using the extended equation (4). The $\alpha_{3}$ coefficient is determined by numerical resolution of equation (4) always assuming a Gaussian temporal and spatial incident intensity distribution, as depicted in relationship (5), because the equation (4) does not give a simple analytical formulation for $T_{n l}$ such as the equation (2) when both $\alpha_{2}$ and $\alpha_{3}$ are non zero:

$$
I(z=0, r, t)=\frac{E}{\pi^{3 / 2} \tau \omega_{0}^{2}} e^{-\frac{t^{2}}{\tau^{2}}} e^{-\frac{2 r^{2}}{\omega_{0}^{2}}}
$$

where $E$ is the total energy, $\tau$ is the HW1/eM pulse duration, and $w_{0}$ is the HW1/e $\mathrm{e}^{2} \mathrm{M}$ beam size.

It is worth noting that similar $\alpha_{3}$ determination have already been performed in the visible part of the spectra $^{31}$ but, to the best of our knowledge, never in the NIR. Simulations of experimental data using the $\alpha_{3}$ approach are represented in green in the Figure 6 and are in agreement with experimental curves.

The $\alpha_{2}^{\text {calcd }}$ and $\alpha_{3}$ values are reported in the Table 2; for 2-6, 2PA coefficients $\alpha_{2}^{\text {calcd }}$ at the telecommunications wavelength of $1500 \mathrm{~nm}$ are comprised between 2 and $5.10^{-11} \mathrm{~m} . \mathrm{W}^{-1}$, twice lower than those measured for the reference inorganic material $\mathrm{GaAs}^{4}$ at $1300 \mathrm{~nm}$. The 3PA coefficients at $1500 \mathrm{~nm}$ are comprised between 150 and $330 \mathrm{~cm}^{3} . \mathrm{GW}^{-2}$ for $\mathbf{2 - 6}$. The precision in the $\alpha_{3}$ determination from equation (5) is illustrated, in the case of the polymethine dye 4, by the bottom part of the Figure 6 in which three fits are represented using $\alpha_{3}=100,200$ or $300 \mathrm{~cm}^{3} . \mathrm{GW}^{-2}$. Clearly blue and red curves ( $\alpha_{3}=100$ and $300 \mathrm{~cm}^{3} \cdot \mathrm{GW}^{-2}$ respectively) represent upper and lower acceptable limits for the experimental data fitting, and therefore the $\alpha_{3}$ value could be estimated to $200+/-100 \mathrm{~cm}^{3} . \mathrm{GW}^{-2}$. The spectral distributions of the 3PA and of 2PA coefficients $\alpha_{3}$ and $\alpha_{2}^{\text {calcd }}$ respectively are compared in Figure 7 between 1300-1600 $\mathrm{nm}$ for the dipolar compound 6. Whereas $\alpha_{2}^{\text {calcd }}$ presents a maximum at $1440 \mathrm{~nm}, \alpha_{3}$ regularly increases up to $1560 \mathrm{~nm}$ and the maximum was not reached in this wavelength range. Assuming that the 3PA results from 2PA followed by ESA, this shift in spectral distributions of $\alpha_{3}$ and $\alpha_{2}^{\text {calcd }}$ allows to deduce at least two observations : (i) it clearly indicates that the existence of a significant ESA process between 1400 and $1600 \mathrm{~nm}$, which is in agreement with ESA spectra of related 
polymethine molecule recorded by a pump-probe technique and that present a transition (attributed to $\mathrm{S}_{1} \rightarrow \mathrm{S}_{2}$ ) in the NIR;32 (ii) the best spectral overlap between 2PA and ESA processes, required for optimization of the effective 3PA process, is not reached and could be yet improved in this family of molecules in order to optimize their OL properties.

\section{Conclusion}

In conclusion, six cyanine-like chromophores designed for nonlinear absorption in the near IR spectral range have been prepared. These molecules present significant $2 \mathrm{PA}$ efficiencies determined by femtosecond Z-scan method, and these systems exhibit optical limiting properties at telecommunications wavelengths $(1500 \mathrm{~nm})$ in nanosecond regime. In the ns pulse regime, the OL experiment were rationalized on the basis of 2PA and the effective 3PA (2PA-induced ESA) processes. Furthermore, this new class of compounds presents many relevant advantages for practical applications (i) an easy two steps synthesis in a gram scale; (ii) a high solubility in organic solvents, due to bulky substituents preventing aggregation and (iii) a good thermal stability. The existence of several sites allowing functionalization for further use in a biological medium or for a grafting in sol-gel / polymeric matrices, will allow the investigation of many different 2PA based applications in the NIR range e.g. solid state optical limiting, biological imaging, signal processing.

\section{Experimental section.}

Crystal structure analysis for $6 . \mathrm{C}_{41} \mathrm{H}_{41} \mathrm{~N}_{4} \mathrm{ClO}, \mathrm{Mr}=641.23$, monoclinic, $\mathrm{P} 2_{1} / \mathrm{a}, \mathrm{a}=11.6162(5), \mathrm{b}=$ 17.0136(8), $\mathrm{c}=18.6513(9) \AA, \beta=92.615(4)^{\circ}, \mathrm{V}=3682.3(3) \AA^{3}, \mathrm{Z}=4, \mathrm{D}_{\mathrm{X}}=1.157 \mathrm{mg} \cdot \mathrm{m}-3, \lambda(\mathrm{MoK} \alpha)$ $=0.71073 \AA, \mu=1.40 \mathrm{~cm}^{-1}, \mathrm{~F}(000)=1360, \mathrm{~T}=295(2) \mathrm{K}$. The sample $(0.30 * 0.28 * 0.22 \mathrm{~mm})$ was studied on an Oxford Diffraction Xcalibur Saphir 3 diffractometer with graphite monochromatized $\mathrm{MoK} \alpha$ radiation. The data collection $\left(2 \theta_{\max }=54^{\circ}\right.$, omega scan frames via $0.7^{\circ}$ omega rotation and 20 s per frame, range HKL : H -15,13 K -18,22 L -23,24) gives 26700 reflections. The data lead to 8675 
independent reflections from which 3336 with $\mathrm{I}>2.0 \sigma(\mathrm{I})$. The structure was solved with SIR-97 ${ }^{33}$ which revealed the non hydrogen atoms of the molecule. After anisotropic refinement, all the hydrogen atoms were found with a Fourier Difference. The whole structure was refined with SHELXL97 ${ }^{34}$ by the fullmatrix least-square techniques (use of $\mathrm{F}$ square magnitude ; $\mathrm{x}, \mathrm{y}, \mathrm{z}, \beta_{\mathrm{ij}}$ for $\mathrm{O}, \mathrm{Cl}, \mathrm{C}$ and $\mathrm{N}$ atoms, $\mathrm{x}, \mathrm{y}, \mathrm{z}$ in riding mode for $\mathrm{H}$ atoms); 425 variables and 3336 observations with $\mathrm{I}>2.0 \sigma(\mathrm{I})$; calc $\mathrm{w}=1 /\left[\sigma^{2}\left(\mathrm{Fo}^{2}\right)\right.$ $\left.+(0.109 \mathrm{P})^{2}\right]$ where $\mathrm{P}=\left(\mathrm{Fo}^{2}+2 \mathrm{Fc}^{2}\right) / 3$ with the resulting $\mathrm{R}=0.057, \mathrm{R}_{\mathrm{W}}=0.162$ and $\mathrm{S}_{\mathrm{W}}=0.812, \Delta \rho<$ $0.69 \mathrm{e} \AA^{-3}$. ORTEP view was made with PLATON 98. ${ }^{35}$ All the calculations were performed on a Silicon Graphics Indy computer. Crystallographic data for the structural analysis has been deposited with the Cambridge Crystallographic Data Centre, (CCDC- 620269)

Optical limiting setup. The nonlinear transmittance measurements (transmission versus incident energy) were performed with a wavelength tuneable laser source: a tripled Q-switched Nd:YAG laser pumping an optical parametric oscillator delivering $7 \mathrm{~ns}$ long pulses. The laser beam was spatially filtered then focused onto the dye solution. Reference energy was taken using a coated wedged flat. The transmitted energy was focused on the signal detector. Typical beam waist $\omega_{0} \approx 60 \mu \mathrm{m}\left(\mathrm{HW} 1 / \mathrm{e}^{2} \mathrm{M}\right)$ was measured at each test wavelength by imaging the focal plane on a InGaAs camera. The dye sample was adjusted at each wavelength so that its transmission under high flux is minimum (open aperture Z-scan). The incident energy was then controlled by combination of an achromatic half-wave plate and a polarizer. Incident energy was measured using a calibrated Germanium probe (Laser Precision RJP-495) and transmitted energy was measured using pyro-electric probe (Laser Precision RJP-735).

Typical beam waist $\omega_{0} \approx 60 \mu \mathrm{m}$ was chosen in order to get high incident energy densities in the sample while achieving a Rayleigh range higher than the $2 \mathrm{~mm}$ thickness of the cells. The beam characteristics and the experimental setup were chosen to minimize the influence of defocusing effects:

- the pulse repetition rate $(10 \mathrm{~Hz})$ is much smaller than the reciprocal thermal diffusion time in the cell $\left(\tau_{\mathrm{d}}=\omega_{0}^{2} / \mathrm{D} \sim 4 \mu \mathrm{s}\right)$. 
- the solvent (dichloromethane) and the beam waist are chosen in order to get a long acoustic transient time $\left(\tau_{\mathrm{ac}}=\omega_{0} / \mathrm{Cs}=60 \mathrm{~ns}\right.$ where $\mathrm{Cs}$ is the speed of sound $):$ the pulse width is small compared to the acoustic transient time. Therefore, the sensitivity of the measurement to nonlinear refraction is reduced. ${ }^{36}$

- the collecting lens aperture ( which is twice the size of the beam in linear regime) and the detector size were chosen so that all the transmitted light is collected and focused onto the detector even under high incident flux.

With these experimental precautions, no aperture losses due to defocusing effects were observed.

General procedures. All reactions were routinely performed under argon. NMR spectra $\left({ }^{1} \mathrm{H},{ }^{13} \mathrm{C}\right)$ were recorded at room temperature on a BRUKER AC 200 operating at $200.13 \mathrm{MHz}$ and 50.32 for ${ }^{1} \mathrm{H}$ and ${ }^{13} \mathrm{C}$ respectively and on a VARIAN Unity Plus operating at $499.84 \mathrm{MHz}$ for ${ }^{1} \mathrm{H}$ NMR. Data are listed in parts per million (ppm) and are reported relative to tetramethylsilane $\left({ }^{1} \mathrm{H},{ }^{13} \mathrm{C}\right)$, residual solvent peaks being used as internal standard $\left(\mathrm{CHCl}_{3}{ }^{1} \mathrm{H}: 7.26 \mathrm{ppm},{ }^{13} \mathrm{C}: 77.36 \mathrm{ppm}\right)$. UV-visible spectra were recorded on a Jasco V-550 spectrophotometer in diluted dichloromethane solution ( $c a$. $\left.10^{-5} \mathrm{~mol}^{-\mathrm{L}^{-1}}\right)$. Infra-Red spectra were recorded on a Mattson 3000 spectrometer using KBR Pellets. Thermogravimetric analysis (TGA) measurements were recorded on a NIETZSCH STA 409 PC/PG under Nitrogen atmosphere. High resolution mass spectrometry measurements were performed at the Service Central d'Analayse du CNRS (Vernaison, France) and at the Centre Commun de Spectrométrie de Masse (UCBL, Villeurbanne, France) and elemental analysis by the Service Central d'Analyse du CNRS (Vernaison, France). Column Chromatography was performed on Merck Gerduran 60 (40-63 $\mu \mathrm{m})$ silica using dichloromethane as eluent. Bis-aldehyde $\mathbf{A}^{11}$ and tricyanofurane ${ }^{37}$ were prepared according published procedures.

Dye 1. 1-hexyl-2-methyl-benzothiazolium bromide (2.5 g, $8 \mathrm{mmol}, 3,6$ equiv.) and A (500 $\mathrm{mg})$ were dissolved in absolute ethanol-pyridine (4:1, $25 \mathrm{~mL})$ under argon. The solution was refluxed for $20 \mathrm{~h}$. After evaporation of the solvent, the mixture was dissolved in dichloromethane $(30 \mathrm{~mL})$ washed with water, dried with $\mathrm{Na}_{2} \mathrm{SO}_{4}$, filtered and the solvent was evaporated. The crude was washed thoroughly 
with diethyl ether and pentane to afford a green solid (1.2 g, 60\%). ${ }^{1} \mathrm{H}$ NMR (200.13 $\left.\mathrm{MHz}, \mathrm{CDCl}_{3}\right)$ : $\delta \quad 0.6-1.0(9 \mathrm{H}, \mathrm{m}), 1.13(9 \mathrm{H}, \mathrm{s}), 1.2-1.7(13 \mathrm{H}, \mathrm{m}), 1.7-2.0(12 \mathrm{H}, \mathrm{m}), 2.02(3 \mathrm{H}, \mathrm{s}), 2.28\left(1 \mathrm{H}, \mathrm{dd}^{2} J=13\right.$ Hz. $\left.{ }^{3} J=13 \mathrm{~Hz}\right), 2.36\left(1 \mathrm{H}\right.$, dd. $\left.{ }^{2} J=13 \mathrm{~Hz} .{ }^{3} J=13 \mathrm{~Hz}\right), 2.9-3.0(1 \mathrm{H}+1 \mathrm{H}, \mathrm{m}), 4.2-4.6(6 \mathrm{H}, \mathrm{m}), 6.38(1 \mathrm{H}$, $\left.\mathrm{d},{ }^{3} J=14 \mathrm{~Hz}\right), 6.42\left(1 \mathrm{H}, \mathrm{d},{ }^{3} J=14 \mathrm{~Hz}\right), 6.9-7.6(12 \mathrm{H}, \mathrm{m}), 8.10\left(1 \mathrm{H}, \mathrm{d},{ }^{3} J=14 \mathrm{~Hz}\right), 8.13\left(1 \mathrm{H}, \mathrm{d},{ }^{3} J=14\right.$ Hz). HRMS (ESI+) $\mathrm{M}=874.4838$ (calcd for $\mathrm{C}_{54} \mathrm{H}_{72} \mathrm{~N}_{3} \mathrm{OS}_{3}$ 874.4836). Anal. calcd. for $\mathrm{C}_{54} \mathrm{H}_{72} \mathrm{~N}_{3} \mathrm{BrOS}_{3} \cdot \mathrm{H}_{2} \mathrm{O}$ : C, 66.70, H, 7.62, N, 4.32; found: C, 66.26, H, 7.36, N, 4.16. UV-Vis $\left(\mathrm{CH}_{2} \mathrm{Cl}_{2}\right)$ : $\lambda_{\max }=825 \mathrm{~nm}\left(\varepsilon_{\max }=240000\right.$ L.mol $\left.{ }^{-1} \cdot \mathrm{cm}^{-1}\right)$

Dye 2. 1-benzyl-2-methyl-benzothiazolium bromide (2.55 g, $8 \mathrm{mmol}, 3.6$ equiv.) and $\mathbf{A}$ (500 mg) were dissolved in absolute ethanol-pyridine (4:1, $25 \mathrm{~mL})$ under argon. The solution was refluxed for $20 \mathrm{~h}$. After evaporation of the solvent, the mixture was dissolved in dichloromethane $(30 \mathrm{~mL})$ washed with water, dried with $\mathrm{Na}_{2} \mathrm{SO}_{4}$, filtered and the solvent was evaporated. The crude was washed thoroughly with ethyl acetate and pentane to afford a green solid $(1.5 \mathrm{~g}, 70 \%) .{ }^{1} \mathrm{H} \mathrm{NMR}\left(499.84 \mathrm{MHz}, \mathrm{CD}_{2} \mathrm{Cl}_{2}\right): \delta$ $1.03(9 \mathrm{H}, \mathrm{s}), 1.52(1 \mathrm{H}, \mathrm{m}), 2.06(3 \mathrm{H}, \mathrm{s}), 2.16\left(1 \mathrm{H}, \mathrm{dd},{ }^{2} J=13 \mathrm{~Hz},{ }^{3} J=12 \mathrm{~Hz}\right), 2.18\left(1 \mathrm{H}, \mathrm{dd},{ }^{2} J=13 \mathrm{~Hz}\right.$, $\left.{ }^{3} J=12 \mathrm{~Hz}\right), 2.71\left(1 \mathrm{H}, \mathrm{dd},{ }^{2} J=13 \mathrm{~Hz},{ }^{3} J=1 \mathrm{~Hz}\right), 2.74\left(1 \mathrm{H}, \mathrm{dd},{ }^{2} J=13 \mathrm{~Hz},{ }^{3} J=1 \mathrm{~Hz}\right), 4.2\left(1 \mathrm{H}, \mathrm{d},{ }^{2} J=15\right.$ Hz), $5.65(4 \mathrm{H}, \mathrm{m}), 5.92\left(1 \mathrm{H}, \mathrm{d},{ }^{2} J=15 \mathrm{~Hz}\right), 6.41\left(1 \mathrm{H}, \mathrm{d},{ }^{3} J=14 \mathrm{~Hz}\right), 6.42\left(1 \mathrm{H}, \mathrm{d},{ }^{3} J=14 \mathrm{~Hz}\right), 6.70$ $\left(1 \mathrm{H}, \mathrm{d},{ }^{3} J=7,5 \mathrm{~Hz}\right), 6.92\left(1 \mathrm{H}, \mathrm{d},{ }^{3} J=7 \mathrm{~Hz}\right), 6.99(1 \mathrm{H}, \mathrm{m}), 7.05-7.65(24 \mathrm{H}, \mathrm{m}), 8.17\left(1 \mathrm{H}, \mathrm{d},{ }^{3} J=14 \mathrm{~Hz}\right)$, $8.19\left(1 \mathrm{H}, \mathrm{d},{ }^{3} \mathrm{~J}=14 \mathrm{~Hz}\right)$. HRSM (ESI+) : $\mathrm{M}^{+}=892.3429$ (Calcd. for $\mathrm{C}_{57} \mathrm{H}_{54} \mathrm{~N}_{3} \mathrm{OS}_{3}:$ 892.3423). Anal. calcd. for $\mathrm{C}_{57} \mathrm{H}_{54} \mathrm{~N}_{3} \mathrm{BrOS}_{3} \cdot \mathrm{H}_{2} \mathrm{O}$ : C, 69.13; H, 5.66; N, 4.24; found: C, 68.99; H 5.45; N, 4.02. UV-Vis $\left(\mathrm{CH}_{2} \mathrm{Cl}_{2}\right) \lambda_{\max }=833 \mathrm{~nm}\left(\varepsilon_{\max }=275000 \mathrm{~L} \cdot \mathrm{mol}^{-1} \cdot \mathrm{cm}^{-1}\right)$

Dye 3. 1-hexyl-2,3,3-trimethylindolenium iodide (1.070 g, $2.8 \mathrm{mmol}, 2.1$ equiv.) and A (0.300 g, 1.3 mmol, 1 equiv.) were dissolved in absolute ethanol (30 mL) under Argon. After addition of pyridine (0.26 mL, $3.2 \mathrm{mmol}, 2.5$ equiv.) the mixture was heated at $40^{\circ} \mathrm{c}$ for $15 \mathrm{~h}$. The resulting green solution was cooled down to room temperature and dichloromethane $(50 \mathrm{~mL})$ was added. The organic layer was washed with an aqueous solution of dilute $\mathrm{HCl}$, water and brine, dried with $\mathrm{Na}_{2} \mathrm{SO}_{4}$ filterd and the solvent was evaporated under vacuum. The crude was dissolved in the minimum amount of dichloromethane and precipitated by addition of pentane. The desired product was obtained by filtration, 
as a green solid (0.740 g, 70\%). ${ }^{1} \mathrm{H}$ NMR (200.13 MHz, $\left.\mathrm{CDCl}_{3}\right): \delta 0.93(6 \mathrm{H}, \mathrm{m}), 1.11(9 \mathrm{H}, \mathrm{s}), 1.4(13 \mathrm{H}$, m), $1.75(12 \mathrm{H}, \mathrm{s}), 1.80-1.96(4 \mathrm{H}, \mathrm{m}), 2.25\left(2 \mathrm{H}, \mathrm{dd},{ }^{3} J=12 \mathrm{~Hz},{ }^{2} J=12 \mathrm{~Hz}\right), 2.90\left(2 \mathrm{H}, \mathrm{d},{ }^{3} J=12 \mathrm{~Hz}\right)$, $4.10\left(4 \mathrm{H}, \mathrm{t},{ }^{3} \mathrm{~J}=7 \mathrm{~Hz}\right), 6.15\left(2 \mathrm{H}, \mathrm{d},{ }^{3} J=14 \mathrm{~Hz}\right), 7.21\left(2 \mathrm{H}, \mathrm{dd},{ }^{3} J=8 \mathrm{~Hz}\right), 7.32\left(2 \mathrm{H}, \mathrm{d},{ }^{3} J=8 \mathrm{~Hz}\right), 7.40-$ $7.50(4 \mathrm{H}, \mathrm{m}), 8.43\left(2 \mathrm{H}, \mathrm{d},{ }^{3} J=14 \mathrm{~Hz}\right) .{ }^{13} \mathrm{C} \mathrm{NMR}\left(50.32 \mathrm{MHz}, \mathrm{CD}_{2} \mathrm{Cl}_{2}\right): \delta 13.7,22.4,26.6,27.1,27.4$, $27.8,27.9,31.3,32.3,42.3,44.7,49.4,100.7,110.9,122.3,125.4,127.1,128.7,141.1,142.1,144.4$, 150.5, 172.6. HRMS (ESI+): $\mathrm{M}^{+}=679.4781$ (calcd. for $\mathrm{C}_{46} \mathrm{H}_{64} \mathrm{~N}_{2} \mathrm{Cl}$ : 679.4758). Anal. calcd. for: $\mathrm{C}_{46} \mathrm{H}_{64} \mathrm{~N}_{2} \mathrm{ClI}: \mathrm{C}, 68.43, \mathrm{H}, 7.99, \mathrm{~N}, 3.47$; found: C, 68.59, H, 8.08, N, 3.25. UV-Vis $\left(\mathrm{CH}_{2} \mathrm{Cl}_{2}\right): \lambda_{\max }=$ $791 \mathrm{~nm}\left(\varepsilon_{\max }=355000 \mathrm{~L} \cdot \mathrm{mol}^{-1} \cdot \mathrm{cm}^{-1}\right)$.

Dye 4. 1-benzyl-2,3,3-trimethylindolenium bromide (2.700 g, $8.2 \mathrm{mmol}, 2.1$ equiv.) and A (0.891 g, 3.9 mmol, 1 equiv.) were dissolved in absolute ethanol $(50 \mathrm{~mL})$ under argon. After addition of pyridine $(0.8$ $\mathrm{mL}, 9.9 \mathrm{mmol}, 2.5$ equiv.), the mixture was heated at $40^{\circ} \mathrm{c}$ for $15 \mathrm{~h}$. The resulting green solution was cooled down to room temperature and dichloromethane $(100 \mathrm{~mL})$ was added. The organic layer was washed with an aqueous solution of dilute $\mathrm{HCl}$, water, brine, dried with $\mathrm{Na}_{2} \mathrm{SO}_{4}$, filtered and the solvant was evaporated under vacuum. The crude was dissolved in the minimum amount of dichloromethane and precipitated by addition of pentane. The desired product was obtained by filtration, as a green solid (2.200 g, 72\%). ${ }^{1} \mathrm{H}$ NMR (200.13 MHz, $\left.\mathrm{CDCl}_{3}\right): \delta 0.98(9 \mathrm{H}, \mathrm{s}), 1.4(1 \mathrm{H}, \mathrm{m}), 1.74(12 \mathrm{H}, \mathrm{s}), 2.05(2 \mathrm{H}, \mathrm{dd}$, $\left.{ }^{3} J=13 \mathrm{~Hz},{ }^{2} J=13 \mathrm{~Hz}\right), 2.6\left(2 \mathrm{H}, \mathrm{dd},{ }^{3} J=2 \mathrm{~Hz},{ }^{2} J=13 \mathrm{~Hz}\right), 5.43\left(2 \mathrm{H}, \mathrm{d},{ }^{2} J=16 \mathrm{~Hz}\right), 5.52\left(2 \mathrm{H}, \mathrm{d},{ }^{2} J=\right.$ $16 \mathrm{~Hz}), 6.18\left(2 \mathrm{H}, \mathrm{d},{ }^{3} J=14 \mathrm{~Hz}\right), 7.2-7.5(18 \mathrm{H}, \mathrm{m}), 8.23\left(2 \mathrm{H}, \mathrm{d},{ }^{3} J=14 \mathrm{~Hz}\right) .{ }^{13} \mathrm{C} \mathrm{NMR}(50.32 \mathrm{MHz}$, $\left.\mathrm{CDCl}_{3}\right): \delta 27.3,28.1,28.2,32.3,41.9,48.4,49.3,102.2,111.1,122.4,125.5,126.6,128.2,128.3,129.0$ 129.2, 134.2, 140.8, 142.7, 144.2, 150.6, 172.5. HRMS (ESI+): $\mathrm{M}^{+}=691.3842$ (calcd. for $\mathrm{C}_{48} \mathrm{H}_{52} \mathrm{~N}_{2} \mathrm{Cl}$ 691.3814). Anal. calcd for $\mathrm{C}_{48} \mathrm{H}_{52} \mathrm{~N}_{2} \mathrm{BrCl}$ : C, 74.65, H, 6.79, N, 3.63, Found C, 74.08, H, 6.90, N, 3.33. UV-Vis $\left(\mathrm{CH}_{2} \mathrm{Cl}_{2}\right): \lambda_{\max }=794 \mathrm{~nm}\left(\varepsilon_{\max }=350000 \mathrm{~L} \cdot \mathrm{mol}^{-1} \cdot \mathrm{cm}^{-1}\right)$.

Dye 5. A (180 mg, $0.78 \mathrm{mmol}, 1$ equiv.) and tricyanofurane (155 mg, 1 equiv.) were dissolved in $\mathrm{n}$ butanol (15 mL) under Argon. After addition of pyridine (0.06 mL, $0.78 \mathrm{mmol}, 1$ equiv.), the mixture was heated at $100^{\circ} \mathrm{C}$ for $1.5 \mathrm{~h}$. A solution of 1-hexyl-2,3,3-trimethylindolenium iodide (376 mg, 1.2 equiv.) in n-butanol $(10 \mathrm{~mL})$ was added. The solution was then heated for $3 \mathrm{~h}$ at $100^{\circ} \mathrm{C}$. The resulting 
green solution was cooled down to room temperature and dichloromethane $(50 \mathrm{~mL})$ was added. The organic layer was washed with an aqueous solution of dilute $\mathrm{HCl}$, water, brine, dried with $\mathrm{Na}_{2} \mathrm{SO}_{4}$, filtered and the solvent was evaporated under vacuum. Purification by column chromatography on silica gel (eluent: dichloromethane) afforded a green solid (170 mg, $35 \%) .{ }^{1} \mathrm{H} \mathrm{NMR}\left(200.13 \mathrm{MHz}, \mathrm{CDCl}_{3}\right): \delta$ $0.9(\mathrm{~m}, 3 \mathrm{H}), 1.04(\mathrm{~s}, 9 \mathrm{H}), 1.2-1.6(\mathrm{~m}, 9 \mathrm{H}), 1.67(\mathrm{~s}, 6 \mathrm{H}), 1.75(\mathrm{~s}, 6 \mathrm{H}), 2.07(\mathrm{~m}, 1 \mathrm{H}+1 \mathrm{H}), 2.81(\mathrm{dd}$ $1 \mathrm{H}+1 \mathrm{H}), 3.82\left(\mathrm{t}, 2 \mathrm{H},{ }^{3} \mathrm{~J}=7 \mathrm{~Hz}\right), 5.70\left(\mathrm{~d}, 1 \mathrm{H},{ }^{3} \mathrm{~J}=13 \mathrm{~Hz}\right), 6.33\left(\mathrm{~d}, 1 \mathrm{H},{ }^{3} \mathrm{~J}=15 \mathrm{~Hz}\right), 6.85\left(\mathrm{~d}, 1 \mathrm{H},{ }^{3} J=8\right.$ $\mathrm{Hz}), 7.04\left(\mathrm{dd}, 1 \mathrm{H},{ }^{3} \mathrm{~J}=8 \mathrm{~Hz}\right), 7.25-7.32(\mathrm{~m}, 2 \mathrm{H}), 7,95\left(\mathrm{~d}, 1 \mathrm{H},{ }^{3} \mathrm{~J}=13 \mathrm{~Hz}\right), 8.12\left(\mathrm{~d}, 1 \mathrm{H},{ }^{3} \mathrm{~J}=15 \mathrm{~Hz}\right) .{ }^{13} \mathrm{C}$ $\operatorname{NMR}\left(50.32 \mathrm{MHz}, \mathrm{CDCl}_{3}\right): \delta 14.4,22.9,27.0,27.2,27.5,27.7,27.8,28.0,28.6,28.8,31.8,32.8,42.8$ $43.8,48.1,93.4,96.2,96.7,108.7,110.8,112.3,112.9,113.7,122.5,123.1,126.4,128.1,128.7,137.2$ 140.3, 143.7, 144.7, 147.7, 166.2, 173.4, 176.8. HRMS (ES+) $\mathrm{MH}^{+}=635.3546$ (calcd. for $\left.\mathrm{C}_{40} \mathrm{H}_{47} \mathrm{~N}_{4} \mathrm{OCl}: 635.3517\right) . \mathrm{UV}-\mathrm{V}$ is $\left(\mathrm{CH}_{2} \mathrm{Cl}_{2}\right): \lambda_{\max }=831 \mathrm{~nm}\left(\varepsilon_{\max }=112000 \mathrm{~L} \cdot \mathrm{mol}^{-1} \cdot \mathrm{cm}^{-1}\right)$

Dye 6. A (172 mg, $0.75 \mathrm{mmol}, 1$ equiv.) and tricyanofurane (151 mg, 1 equiv.) were dissolved in $\mathrm{n}$ butanol (15 mL) under Argon. After addition of pyridine (0.06 mL, $0.78 \mathrm{mmol}, 1.1$ equiv.), the mixture was heated at $100^{\circ} \mathrm{C}$ for $1.5 \mathrm{~h}$. A solution of 1-benzyl-2,3,3-trimethylindolenium iodide (300 mg, 1.2 equiv.) in n-butanol $(10 \mathrm{~mL})$ was added. The solution was then heated for $3 \mathrm{~h}$ at $100^{\circ} \mathrm{C}$. The resulting green solution was cooled down to room temperature and dichloromethane $(50 \mathrm{~mL})$ was added. The organic layer was washed with an aqueous solution of dilute $\mathrm{HCl}$, water, brine, dried with $\mathrm{Na}_{2} \mathrm{SO}_{4}$ and filtrated. The solvent was evaporated under vacuum. Purification by column chromatography on silica gel (eluent: dichloromethane) afforded a green solid (300 mg, 30\%). ${ }^{1} \mathrm{H}$ NMR (200.13 MHz, $\left.\mathrm{CDCl}_{3}\right): \delta$ $0.97(\mathrm{~s}, 9 \mathrm{H}), 1.49(\mathrm{~m}, 1 \mathrm{H}), 1.70(\mathrm{~s}, 6 \mathrm{H}), 1.75(\mathrm{~s}, 6 \mathrm{H}), 2.08(\mathrm{~m}, 1 \mathrm{H}+1 \mathrm{H}), 2.65(\mathrm{~m}, 1 \mathrm{H}+1 \mathrm{H}), 4.93(\mathrm{~d}, 1 \mathrm{H}$ $\left.{ }^{2} J=16 \mathrm{~Hz}\right), 4.99\left(\mathrm{~d}, 1 \mathrm{H},{ }^{2} J=16 \mathrm{~Hz}\right), 5.63\left(\mathrm{~d}, 1 \mathrm{H},{ }^{3} J=13 \mathrm{~Hz}\right), 6.35\left(\mathrm{~d}, 1 \mathrm{H},{ }^{3} J=16 \mathrm{~Hz}\right), 6.88\left(\mathrm{~d}, 1 \mathrm{H},{ }^{3} J\right.$ $=8 \mathrm{~Hz}), 7.06\left(\mathrm{~d}, 1 \mathrm{H},{ }^{3} \mathrm{~J}=8 \mathrm{~Hz}\right), 7.1-7.4(\mathrm{~m}, 7 \mathrm{H}), 7.85\left(\mathrm{~d}, 1 \mathrm{H},{ }^{3} J=13 \mathrm{~Hz}\right), 8.08\left(\mathrm{~d}, 1 \mathrm{H},{ }^{3} J=16 \mathrm{~Hz}\right) .{ }^{13} \mathrm{C}$ $\operatorname{NMR}\left(50.32 \mathrm{MHz}, \mathrm{CDCl}_{3}\right): \delta 27.1,27.2,27.4,27.6,28.4,28.5,32.3,42.3,47.0,47.4,94.0,96.5,96.9$ $108.1,111.1,111.6,112.3,113.1,122.2,122.6,126.5,126.7,128.0,128.1,128.4,129.2,135.3,135.7$ 139.6, 143.9, 144.4, 146.9, 164.8, 173.2, 176.2. $\mathrm{MS}(\mathrm{ESI}+): \mathrm{MH}^{+}=641.3047$ (calcd for $\mathrm{C}_{41} \mathrm{H}_{41} \mathrm{ClN}_{4} \mathrm{O}$ : 
641.3042). Anal. calcd for: $\mathrm{C}_{41} \mathrm{H}_{41} \mathrm{ClN}_{4} \mathrm{O}: \mathrm{C}$, 76.79, H, 6.44, N, 8.74, Found: C, 76.61, H, 6.53, N, 8.45.

UV-Vis $\left(\mathrm{CH}_{2} \mathrm{Cl}_{2}\right): \lambda_{\max }=810 \mathrm{~nm}\left(\varepsilon_{\max }=91000 \mathrm{~L} \cdot \mathrm{mol}^{-1} \cdot \mathrm{cm}^{-1}\right)$. IR ( KBr pellet $) v_{\mathrm{C} \equiv \mathrm{N}} 2218 \mathrm{~cm}^{-1}$.

Acknowledgements. Authors thank the Direction Générale de l'Armement for a grant to PAB.

Supporting Information Available: Crystallographic data of compound 6 in CIF files, this material is available free of charge via the Internet at http://pubs.acs.org. 


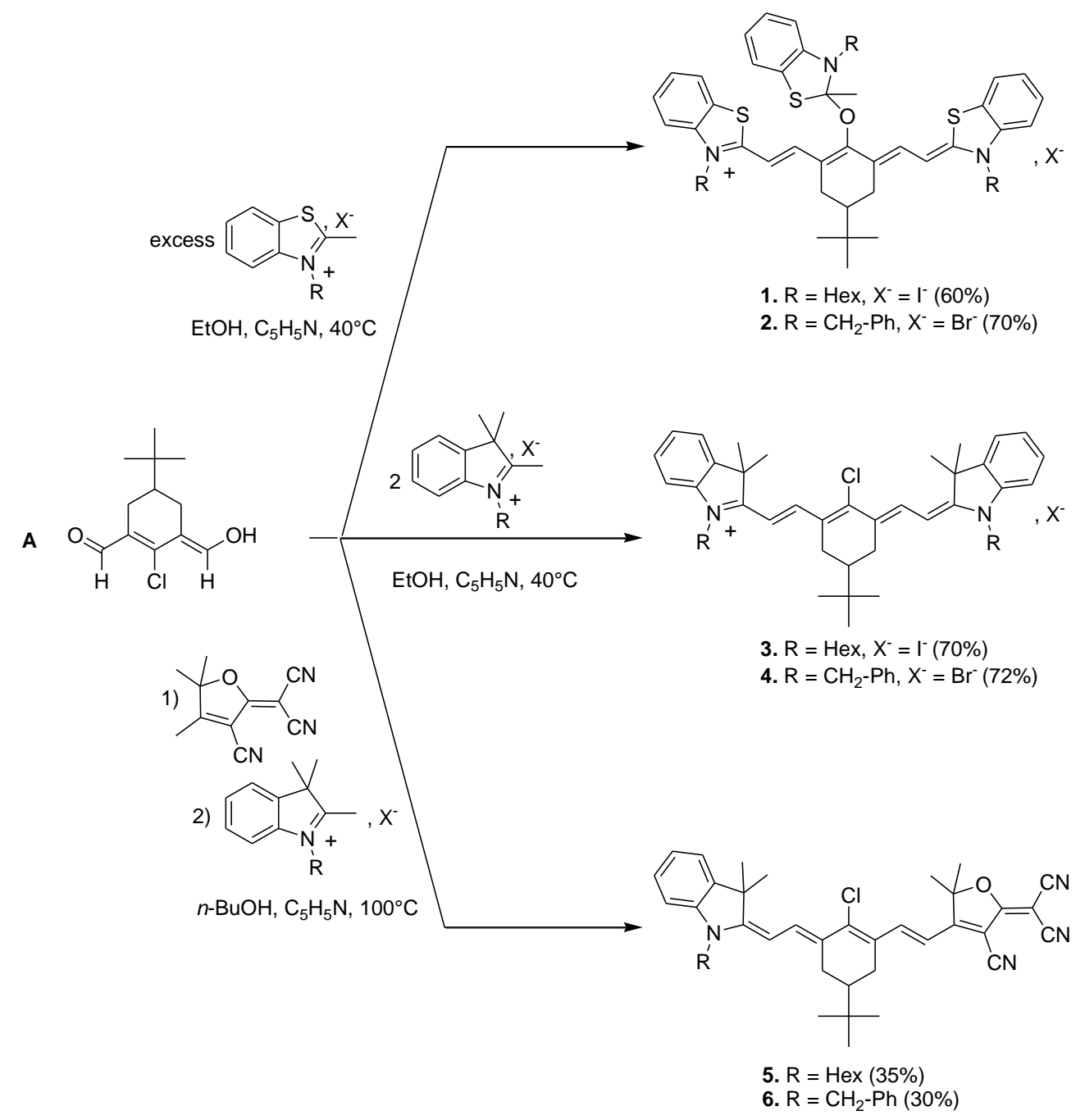

Scheme 1. Synthesis of the target chromophores. 


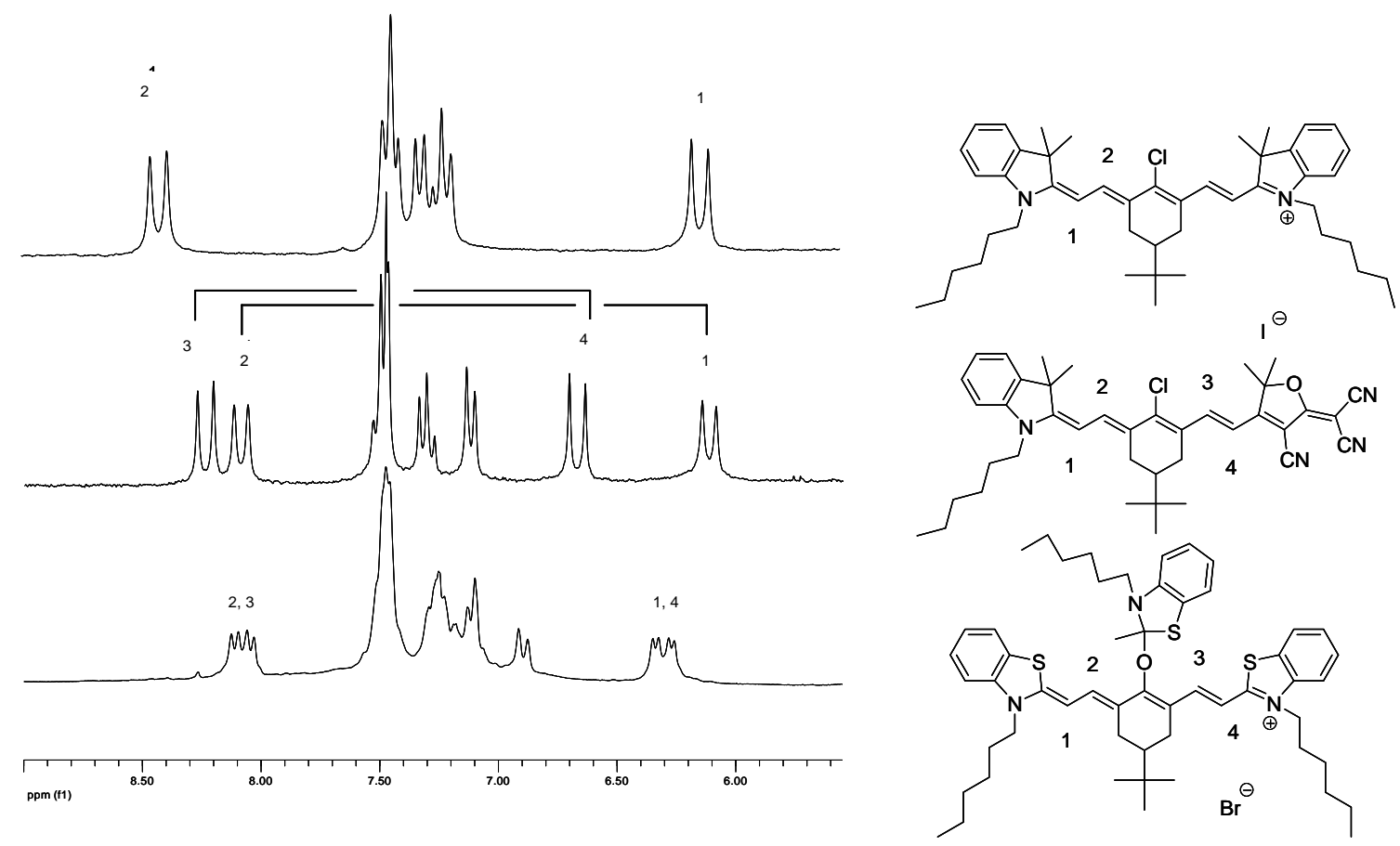

Figure 1. Comparison of the aromatic region of the ${ }^{1} \mathrm{H}$ NMR spectra $\left(200.13 \mathrm{MHz}, \mathrm{CDCl}_{3}, \mathrm{RT}\right)$ for 3 (up), $\mathbf{5}$ (middle) and $\mathbf{1}$ (down). 


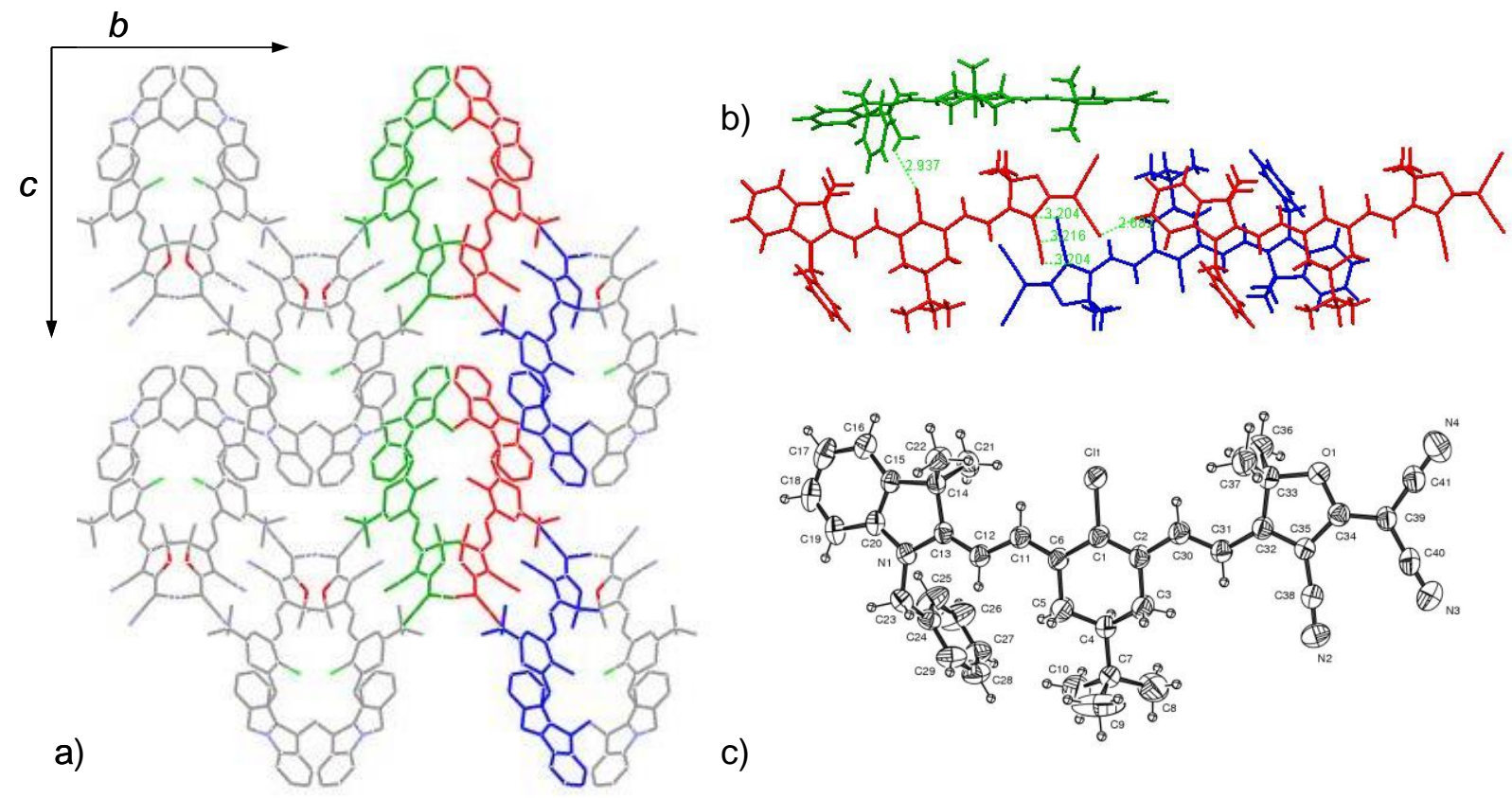

Figure 2. Crystallographic structure of 6: a) view of the crystal packink along the $a$ axix; b) details of the intermolecular interactions; c) ORTEP drawing. Selected distances $(\AA) \mathrm{N}(1)-\mathrm{C}(13) 1.382(3), \mathrm{C}(13)-$ $\mathrm{C}(12) 1.360$ (3), C(12)-C(11) 1.419 (3), C(11)-C(6) 1.358 (3), C(6)-C(1) 1.442 (3), C(1)-C(2) 1.360 (3), $\mathrm{C}(2)-\mathrm{C}(30) 1.423$ (3), $\mathrm{C}(30)-\mathrm{C}(31) 1.363$ (3), $\mathrm{C}(31)-\mathrm{C}(32) 1.415$ (3), $\mathrm{C}(32)-\mathrm{C}(35) 1.369$ (3), C(35)C(34) 1.429 (3), C(34)-C(39) 1.378 (3). 


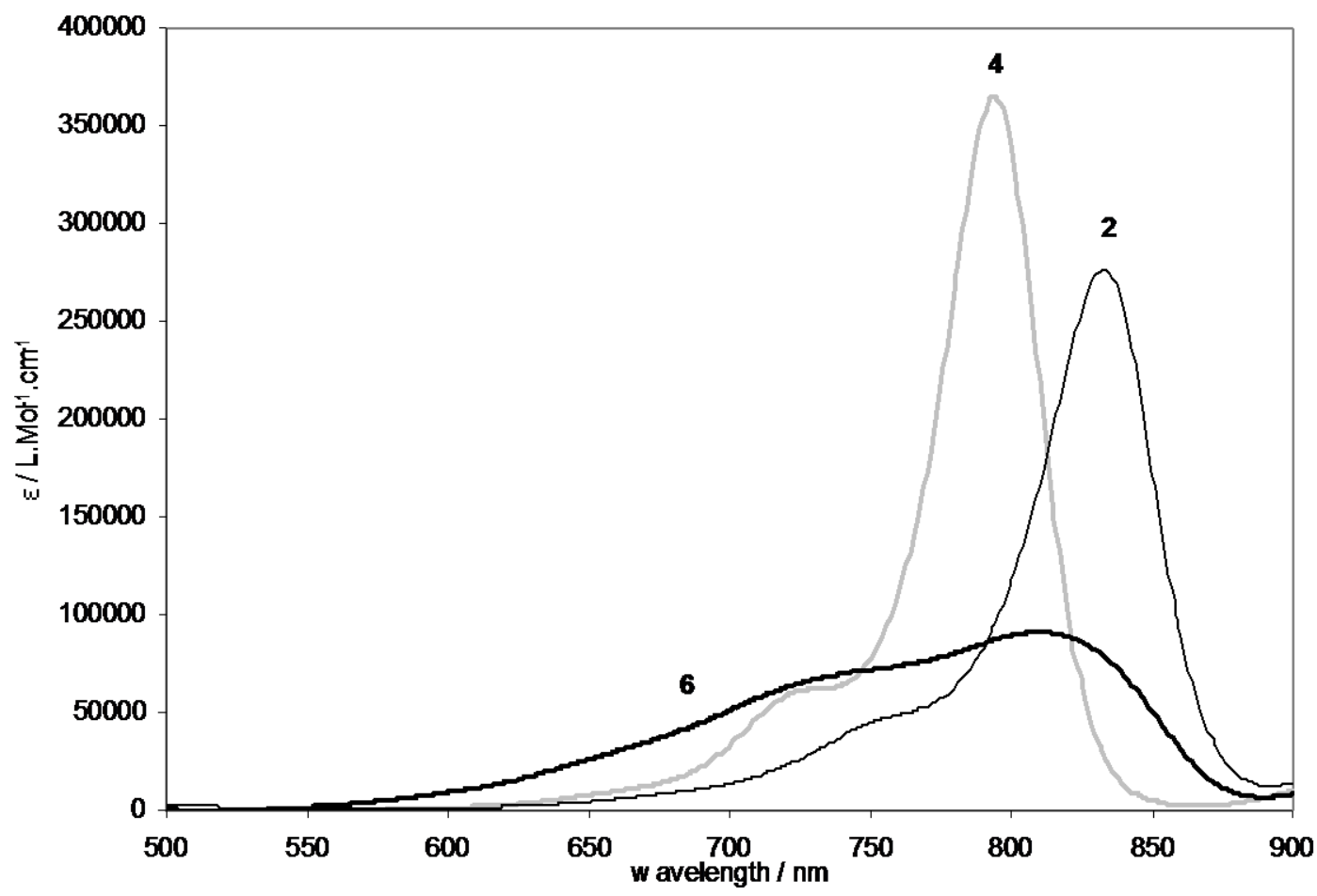

Figure 3. UV-vis-NIR absorption spectra for $\mathbf{2}$ (thin black), $\mathbf{4}$ (gray) and $\mathbf{6}$ (black) in dichloromethane. 
Table 1. Photophysical data in dichloromethane solution.

\begin{tabular}{lccccc}
\hline Compound & $\lambda$ max & $\varepsilon_{\max }$ & $\lambda^{(2)}$ & $\sigma_{2 P A}^{\max }$ & $\begin{array}{c}\mathrm{Td}_{5-10} \\
\end{array}$ \\
& $/ \mathrm{nm}$ & $/{\mathrm{L} . \mathrm{Mol}^{-1} \cdot \mathrm{cm}^{-1}}$ & $/ \mathrm{nm}^{\mathrm{a}}$ & $/ \mathrm{GM}^{\mathrm{b}}$ & $/{ }^{\circ} \mathrm{C}^{\mathrm{c}}$ \\
\hline $\mathbf{1}$ & 825 & 240000 & - & - & $200-210$ \\
$\mathbf{2}$ & 833 & 270000 & 1495 & 544 & $205-225$ \\
$\mathbf{3}$ & 791 & 355000 & - & - & $240-245$ \\
$\mathbf{4}$ & 794 & 350000 & 1437 & 731 & $240-245$ \\
$\mathbf{5}$ & 831 & 112000 & - & - & $225-250$ \\
$\mathbf{6}$ & 810 & 91000 & 1445 & 792 & $274-277$ \\
\hline
\end{tabular}

a maximal two-photon absorption wavelength ${ }^{\mathrm{b}}$ maximal two-photon absorption cross-section measured by femtosecond Z-scan technique, ${ }^{\mathrm{c}}$ decomposition temperature at 5 and $10 \%$ weigth loss, quoted to the $5^{\circ} \mathrm{C}$ inferior, measured by thermogravimetric analysis (TGA) under nitrogen. 

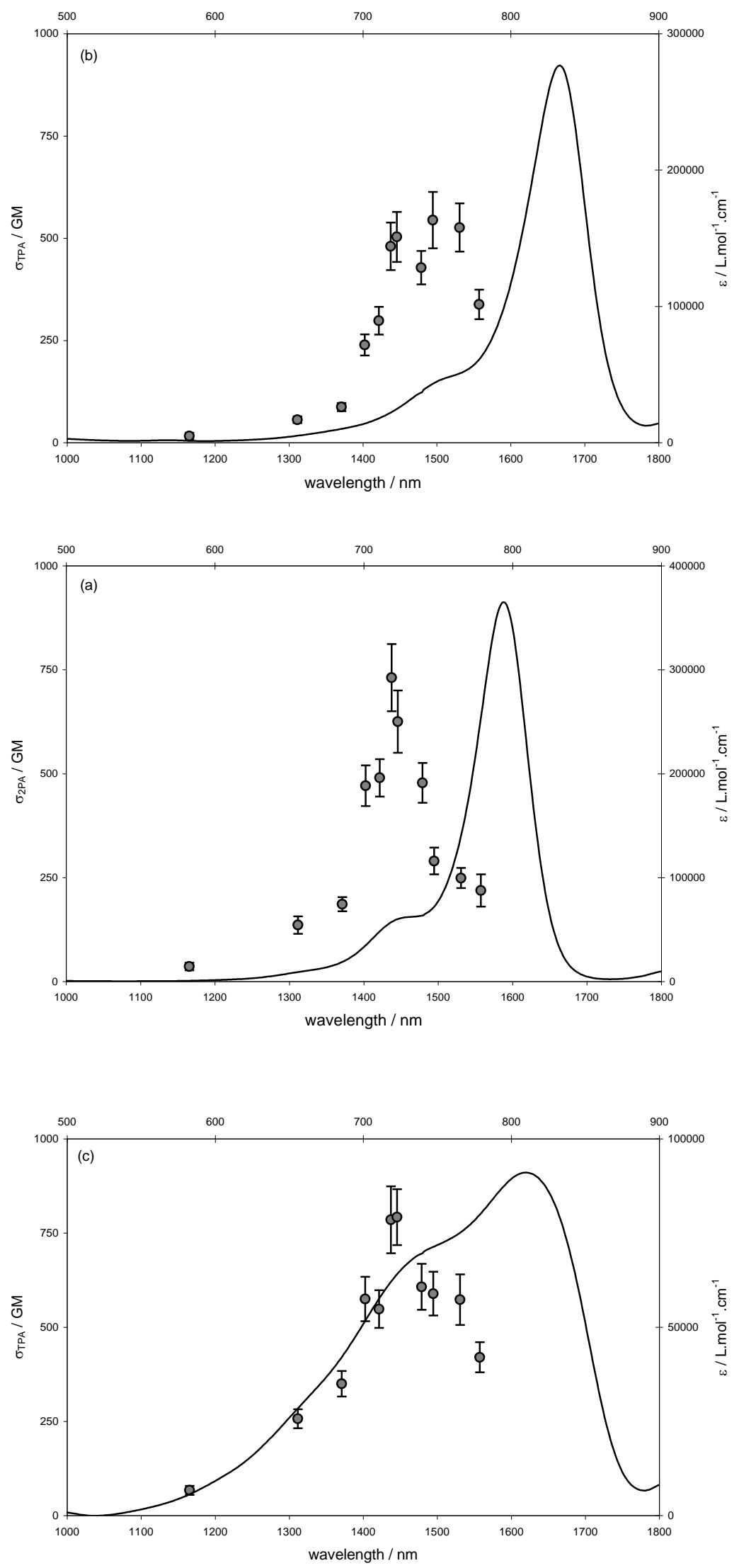

Figure 4. 2PA spectra measured by fs-Z-scan method (filled circle) and 1PA spectra in upper abscissa (-) of compounds 2 (a), 4 (b) and 6 (c) in dichloromethane solution. 


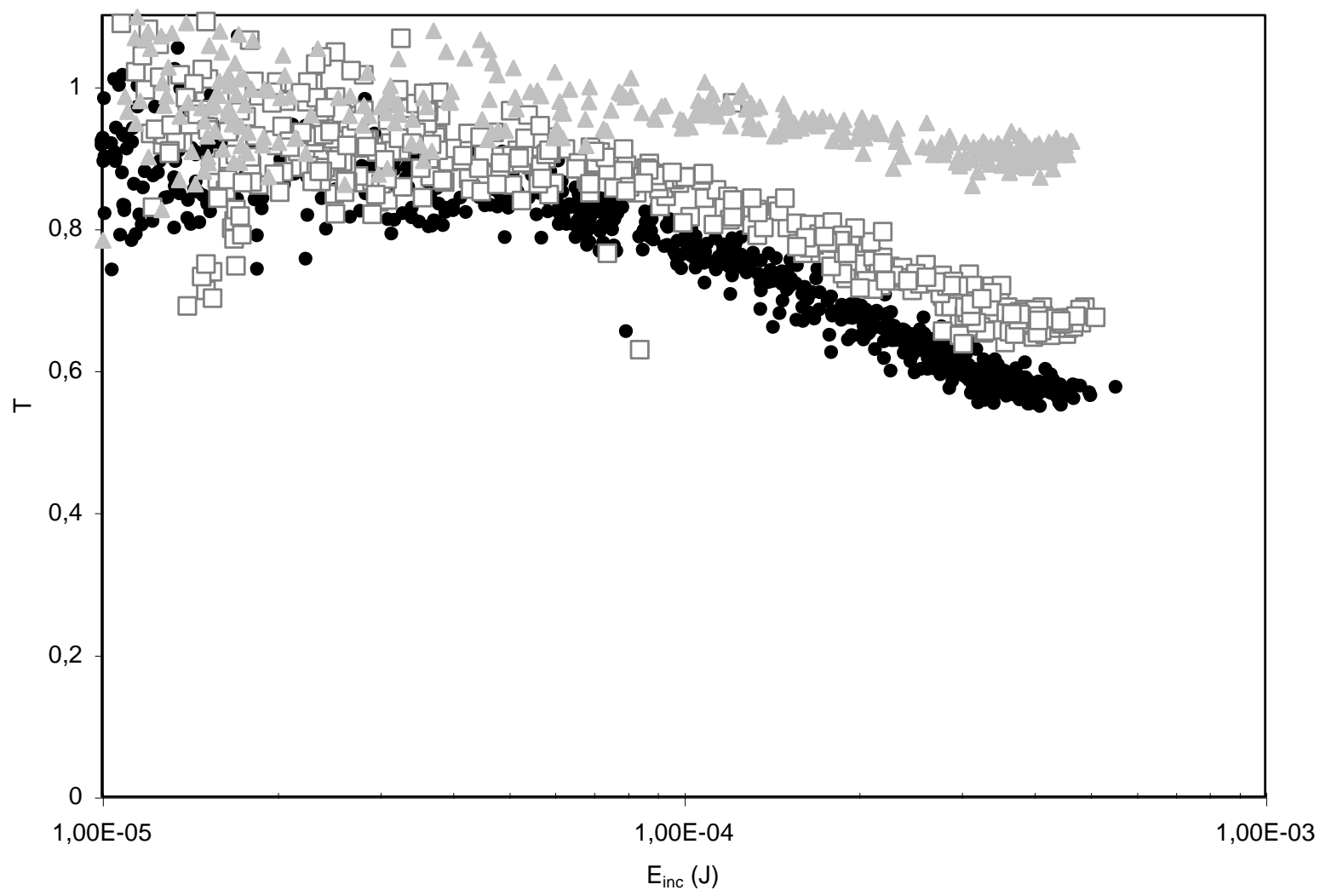

Figure 5. Nonlinear transmittance of $\mathbf{1}$ using $1500 \mathrm{~nm}$ as incident wavelength in dichloromethane solutions of different concentrations: $\mathrm{C}_{1}=223.4$ g. $\mathrm{L}^{-1}$ (gray triangle); $\mathrm{C}_{2}=281.6$ g.L $\mathrm{L}^{-1}$ (open square); $\mathrm{C}_{3}$ $=320.4 \mathrm{~g} \cdot \mathrm{L}^{-1}$ (black circle). 

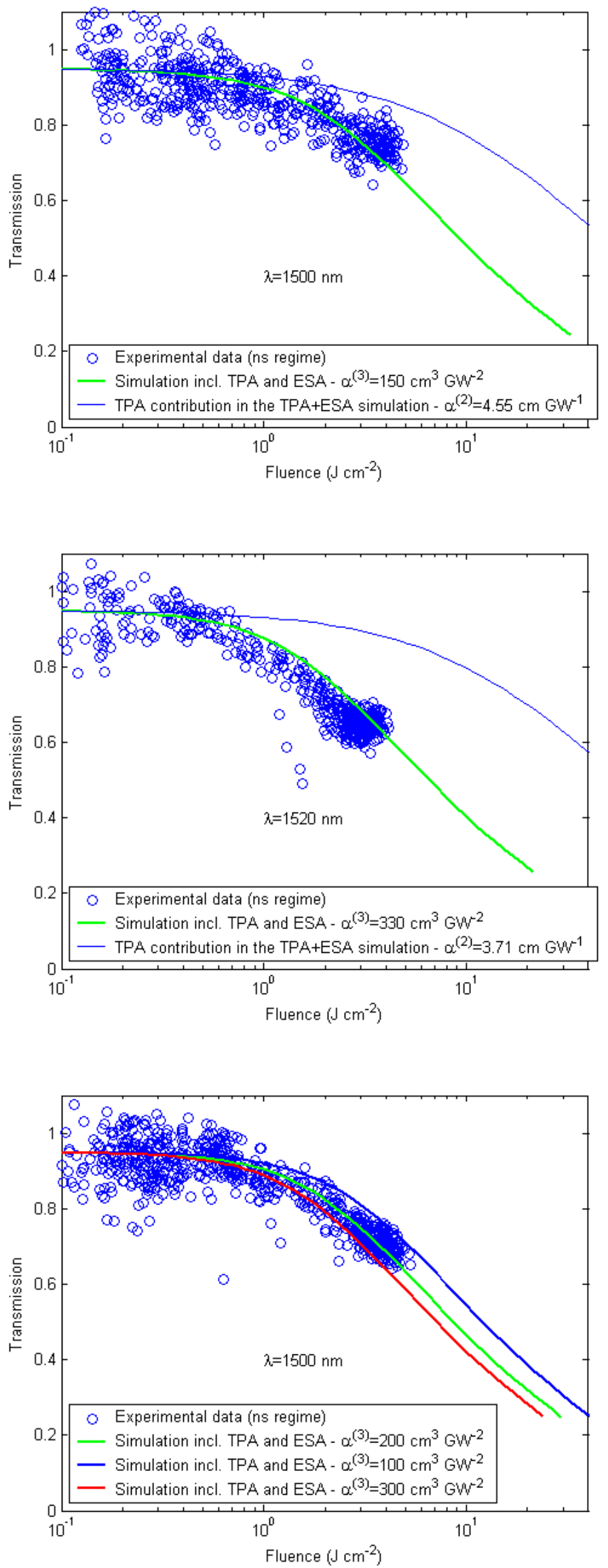
Figure 6. Nonlinear transmittance of $\mathbf{2}$, (up) $\mathbf{6}$ (middle) in concentrated dichloromethane solution (experimental data points and theoretical simulations using simplified 2PA model (red) or complete model including 2PA and ESA (green), including only the 2PA contribution within this latter hypothesis (blue)). Nonlinear transmittance of 4 (bottom) with theoretical simulations using different $\alpha_{3}$ coefficients.

Table 2. 2PA and 3PA data using different models.

\begin{tabular}{cccccc}
\hline & & & \multicolumn{2}{c}{ fs Z-scan } & 2PA+ ESA \\
& $\mathrm{C}^{\mathrm{a}}$ & $\lambda^{\mathrm{b}}$ & $\sigma_{2 \mathrm{PA}}{ }^{\mathrm{c}}$ & $\alpha_{2}^{\text {calcd }}$ & $\alpha_{3}{ }^{\mathrm{d}}$ \\
& $\mathrm{g} . \mathrm{L}^{-1}$ & $\mathrm{~nm}$ & $\mathrm{GM}$ & $\mathrm{cm} \cdot \mathrm{GW}^{-1}$ & $\mathrm{~cm}^{3} \cdot \mathrm{GW}^{-2}$ \\
\hline $\mathbf{2}$ & 112.6 & 1500 & 530 & 4.55 & 150 \\
$\mathbf{4}$ & 96.5 & 1500 & 280 & 1.59 & 200 \\
$\mathbf{6}$ & 92.3 & 1440 & 792 & 5.02 & 190 \\
& & 1520 & 560 & 3.71 & 330
\end{tabular}

${ }^{a}$ experimental concentration used in optical limiting measurements $;{ }^{b}$ maximal two-photon absorption wavelength; ${ }^{\mathrm{c}}$ from femtosecond Z-scan measurement ; ${ }^{\mathrm{d}}$ determined from OL experiments using complete model. 


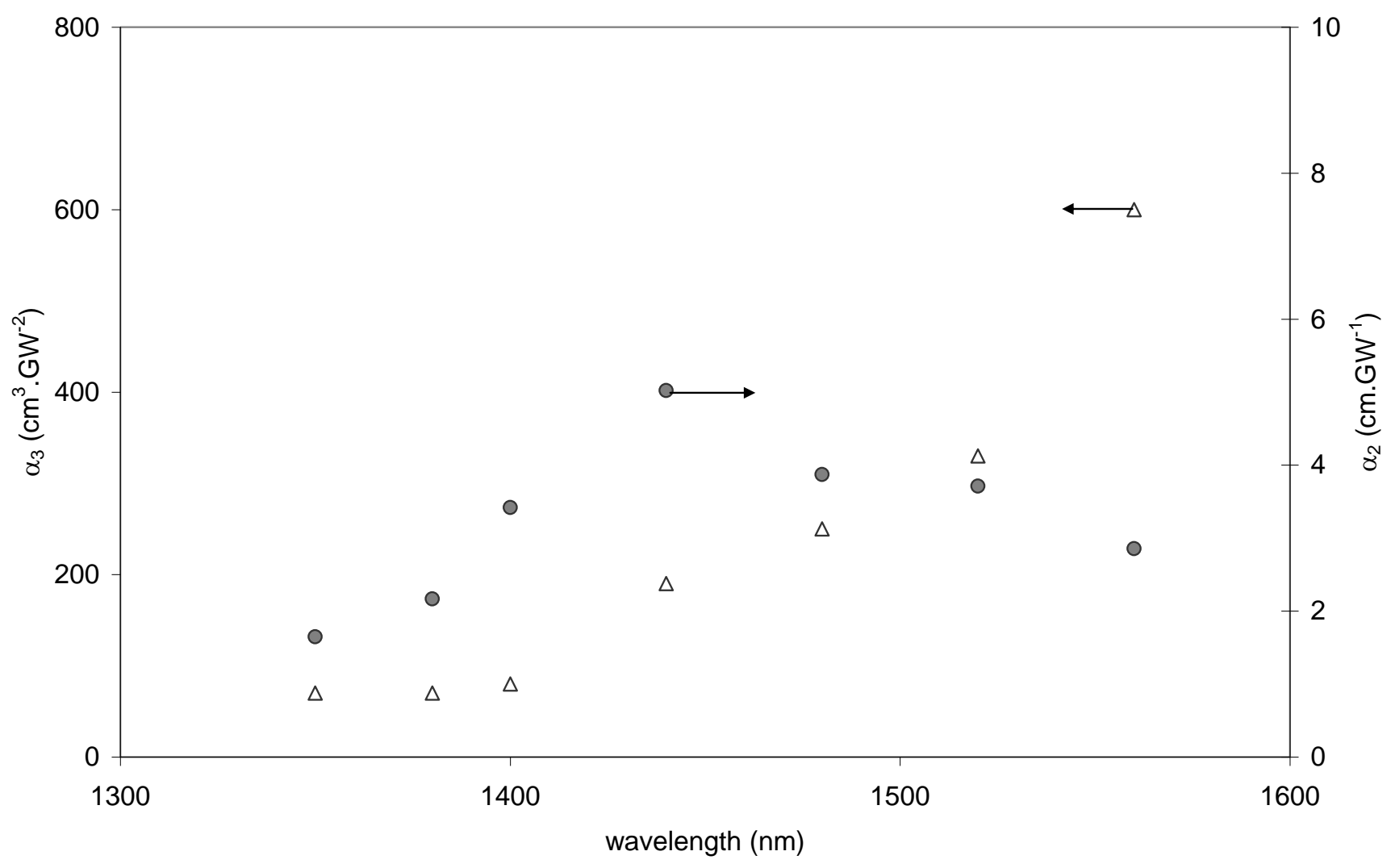

Figure 7. Spectral variation of $\alpha_{3}$ coefficient (gray circle) deduced from OL experiment and $\alpha_{2}^{\text {calcd }}$ coefficient calculated from fs Z-scan measurement (open triangle) in the case of $\mathbf{6}$.

\section{References and notes.}

1 For selected example of two-photon applications see : a) Cumpston, B.H.; Ananthavel, S.P.; Barlow, S.; Dyer, D.L.; Ehrlich, J.E.; Erskine, L.L.; Heikal, A.A.; Kuebler, S.M.; Sandy-Lee, I.-Y.; McCordMaughon, D.; Qin, J.; Röckel, H.; Rumi, M.; Wu, X.-L.; Marder, S.R.; Perry, J.R. Nature, 1999, 398, 51-54; b) Wang, S.; Gang, Q.; Zhang, Y.; Li, S.; Xu, H.; Yang, G.; Chem. Phys. Chem., 2006, 7, 935941; c) Dini, D.; Calvete, M.J.F.; Hanack, M.; Amendola, V.; Meneghetti, M. Chem. Commun., 2006, 2394-2396; d) Anémian, R.; Morel, Y.; Baldeck, P.L.; Paci, B.; Kretsch, K.; Nunzi, J.-M.; Andraud, C. J. Mat. Chem., 2003, 13, 2157-2163; e) Kawata, S.; Sun, H.-B.; Tanaka, T.; Takada, K. Nature, 2001, 412, 697-698; f) Belfield, K.D.; Ren, X.; Van Stryland, E.W.; Hagan, D.J.; Dubikovsky, V.; Miesak, E.J. J. Am. Chem. Soc., 2000, 122, 1217-1218; g) Klein, S.; Barsella, A.; Leblond, H.; Bulou, H.; Fort, 
A.; Andraud, C.; Lemercier, G.; Mulatier, J.C.; Dorkenoo, K. Appl. Phys. Lett., 2005, 86, 211118; h) Yuste, R. Nature Methods, 2005, 2, 902-904; i) Campagnola, P.J.; Loew, L.M. Nature Biotechnol., 2003, 21, 1356-1360; j) Zipfel, W.R.; Williams, R.M.; Webb, W.W. Nature Biotechnol., 2003, 21, 1356-1360; k) Nikolenko, V.; Yuste, R.; Zayat, L.; Baraldo, L.M.; Etchenique, R. Chem. Commun., 2005, 1752-1754; 1) Wecksler, S.R.; Mikhailowsky, A.; Korystov, D.; Ford, P.C. J. Am. Chem. Soc. 2006, 128, 3831-3837; m) Fredericksen, P.K.; Jorgensen, M.; Ogilby, P.R. J. Am. Chem. Soc. 2001, 123, 1215-1221; n) Oar, M.A.; Serin, J.M.; Dichtel, W.R.; Fréchet, J.M.J.; Ohulchanskyy, T.Y.; Prasad, P.N. Chem. Mater., 2005, 17, 2267-2275.

2 For a review see: Spangler, C.W. J. Mater. Chem., 1999, 9, 2013-2020 and references therein.

3 For selected examples see : a) Cha, M.; Saricifti, N.S.; Heeger, A.J.; Hummelen, J.C.; Wudl, F. App. Phys. Lett, 1995, 67, 3850-3853; b) Morel, Y.; Irimia, A.; Najechalski, P.; Kervella, Y.; Stephan, O.; Baldeck, P.L.; Andraud, C. J. Chem. Phys., 2001, 114, 5391-5396; c) Anémian, R; Mulatier, J.C.; Andraud, C.; Morel, Y.; Stephan, O.; Baldeck, P.L. Proceedings SPIE 2002, 4797, 25-3; d) Charlot, M.; Izard, N.; Mongin, O.; Riehl, D.; Blanchard-Desce, M. Chem. Phys. Lett., 2006, 417, 297-302; e) Dini, D.; Calvete, M.J.F.; Hanack, M.; Amendola, V.; Meneghetti, M. Chem. Commun., 2006, 2394-2396; f) Wang, S.; Gan, Q., Zhang, Y.; Li, S.; Xu, H.; Yang, G. ChemPhysChem, 2006, 7, 935-941; g) McEwan, K.; Lewis, K.; Yang, G.-Y.; Chng, L.L.; Lee, Y.-W; Lau, W.-P.; Lai, K.-S. Adv. Funct. Mater., 2003, 13, 863-867; h) Zhou, G.-J.; Wong, W.-Y.; Lin, Z.; Ye, C. Angew. Chem. Int. Ed., 2006, 45, 6189-6193. 4 Van Stryland, E.; Woodall, M.A.; Van der Zeele, H.; Soileau, M.J. Opt. Lett., 1985, 10, 490-492.

5 a) Hales, J.H.; Zheng, S.; Barlow, S.; Marder, S.R.; Perry J.W. J. Am. Chem. Soc., 2006, 128, 1136211363; b) L. Beverina, J. Fu, A. Leclercq, E. Zojer, P. Pacher, S. Barlow, E.W. Van Stryland, D.J. Hagan, J.-L. Brédas, S.R. Marder,. J. Am. Chem. Soc., 2005, 127, 7282-7283.

6 Zheng, S.; Leclercq, A.; Fu, J.; Beverina, L.; Padilha, L. A.; Zojer, E.; Schmidt, K.; Barlow, S.; Luo, J.; Jiang, S.-H.; Jen, A. K.-Y.; Yi, Y.; Shuai, Z.; Van Stryland, E. W.; Hagan, D. J.; Bredas, J. L.; Marder, S. R. Chem. Mater. 2007, 19(3), 432-442. 
7 Chung, S.-J., Zheng, S.; Odani, T. Beverina, L.; Fu, J.; Padilha,L.A.; Biesso, A.; Hales, J.M.; Zhan, X.; Schmidt, K.; Ye, A.; Zojer, E.; Barlow, S.;Hagan, D.J.; Van Stryland, E.W.; Yi, Y.; Shuai, Z.; Pagani, G.A.; Brédas, J.-L.; Perry, J.W.; Marder, S.R. J. Am. Chem. Soc., 2006, 128, 14445-14446.

8 a) Kurotobi, K.; Kim, K.S.; Noh, S.B.; Kim, D.; Osuka, A. Angew. Chem. Int. Ed., 2006, 45, 39443947; b) Drobizhev, M.; Stepanenko, Y.; Rebane, A.; Wilson, C.J.; Screen, T.E.O.; Anderson, H.L. J. Am. Chem. Soc., 2006, 128, 12432-12433.

9 Kamada, K.; Ohta, K.; Kubo, T.; Shimizu, A.; Morita, Y.; Nakasuji, K.; Kishi, R.; Ohta, S.; Furukawa, S.-I.; Takahashi, H.; Nakano, M. Angew. Chem. Int. Ed. 2007, 46, 3544-3546.

10 Cho, J.Y.; Barlow S., Marder, S.R.; Fu, J.; Padiha, L.A.; Van Stryland E.W.; Bishop, M. Opt. Lett. 2007, 32, 671-673.

11 a) Lin, T.-C.; He, G.S.; Zheng, Q.; Prasad, P.R. J. Mater. Chem. 2006, 16, 2490-2498; b) Q. Zheng, G.S. He, C. Lu, P.N. Prasad J. Mater. Chem. 2005, 16, 3488-3493.

12 Kamanina, N.V.; Bagrov, I.V.; Belousova, I.M.; Kognovitskii, S.O.; Zhevlakov, A.P. Opt. Commun. 2001, 194, 367-372; b) Kamanina, N.V.; Voronin, Y.M.; Varnaev, A.V.; Bagrov, I.V.; Zhevlakov, A.P. Synth. Met. 2003, 138, 317-322.

13 For a general review on cyanine dyes see : Mishra, A.; Behera, R.K.; Behera, P.K.; Mishra, B.K.; Behera, G.B. Chem. Rev., 2000, 100, 1973-2011.

14 a) Kiyose, K.; Kojima, H.; Urano, Y.; Nagano, T. J. Am. Chem. Soc., 2006, 128, 6548-654; b) Li, C.; Greenwood, T.R.; Bhujwalla, Z.M.; Glunde, K. Org. Lett., 2006, 8, 3623-3626; c) Peng, X.; Song, F.; Lu, E.; Wang, Y.; Zhou, W.; Fan, J.; Gao, Y. J. Am. Chem. Soc., 2005, 127, 4170-4171; d) Sasaki, E.; Kojima, H.; Nishimatsu, H.; Urano, Y.; Kikuchi, K.; Hirata, Y.; Nagano, T. J. Am. Chem. Soc., 2005, $127,3684-3685$ and references therein.

15 Reynolds, G.A.; Drexhage, K.H. J. Org. Chem., 1977, 42, 885-888.

16 Narayan, N.; Patonay, G. J. Org. Chem., 1995, 60, 2391-2395.

17 Ramos, S.S.; Santos, P.F.; Reis, L.V.; Almeida, P. Dyes and Pigments, 2002, 53, 143-152. 
18 Related dipolar compounds have been already reported but they feature very low solubility : Kay, A.J.; Woolhouse, A.D.; Zhao, Y.; Clays, K. J. Mater. Chem, 2004, 14, 1321-1330.

19 For instance, both compounds featuring benzothiazole fragments rapidly decomposed on column chromatography over silica or alumina, certainly due to the presence of the reactive sulphur atoms.

20 For other polyene crystal structures see for example a) Shu, C.-F.; Shu, Y.-C.; Gong, Z.-H.; Peng, S.M.; Lee, G.-H.; Jen, A.K.Y. Chem. Mater., 1998, 10, 3284-3286; b) Brotin, T.; Andraud, C.; Ledoux, I.; Brasselet, S.; Zyss, J.; Perrin, M.; Thozet, A.; Collet, A. J. Am. Chem. Soc., 1996, 118, 890-906.

21 Lepkowicz, R.S.; Przhonska, O.V.; Hales, J.M.; Fu, J.; Hagan, D.J.; Van Stryland, E.W.; Bondar, M.V.; Slominsky, Y.L.; Kachkovski, A.D. Chem. Phys., 2004, 305, 259-270.

22 Detailed studies of the photophysical properties will be reported elsewhere.

23 Asato, A.E.; Watanabe, D.T.; Liu, R.S.H. Org. Lett., 2000, 2, 2559-2562.

24 Kamada, K.; Matsunaga, K.; Yoshino, A.; Ohta, K.; J. Opt. Soc. Am. B, 2003, 20, 529-537.

25 Sheik-Bahae, M.; Said, A.A; Wei, T.-H.; Hagan, D.J.; Van Stryland, E.W.; IEEE J. Quant. Electron., 1990, 26, 760-769.

26 Sutherland, R.L.; "Handbook of Nonlinear Optics” 2nd ed. (Marcel Dekker Inc., New York, 2003) p.583.

27 The further details of the analysis procedure are previously provided in Tykwinski, R.R.; Kamada, K.; Bykowski, D.; Hegmann, F.A.; Hinkle, R.J.; J. Opt. A, Pure Appl. Opt., 2002, 4, S202-S206 and the supporting information of Ogawa, K.; Ohashi, A.; Kobuke, Y.; Kamada, K.; Ohta, K. J. Am. Chem. Soc., 2003, 125, 13356-13357.

28 Mahr, H.; “Two-Photon Absorption Spectroscopy” in “Quantum Electronics: A Treatise, Vol. 1, Nonlinear Optics Part A”, Rabin, H.; Tang, C.L.; eds. (Academic Press, New York, 1975) Chap. 4, pp 306-308.

29 Fu, J.; Przhonska, O. V.; Padilha, L.A., Hagan, D. J.; Van Stryland, E. W.; Belfield, K. D.; Bondar, M. V.; Slominsky, Y. L.; Kachkovski, Chem Phys., 2006, 321, 257-268. 
30 a) Swiatkiewicz, J.; Prasad, P.N., Reinhardt, Opt. Commun., 1998, 157, 135-138; b) Kim, O.-K.; Lee, K.-S.; Woo, H.Y.; Kim, K.-S; He, G.S.; Swiatkiewicz, J.; Prasad, P.N., Chem. Mater., 2000, 12, 284286; c) Lei, H.; Wang, H.Z.; Wei, Z.C.; Tang, X.J.; Wu, L.Z.; Tung, C.H.; Zhou, G.Y.; Chem. Phys. Lett., 2001, 333, 387-390.

31 a) Morel, Y.; Irimia, A.; Najechalski, P.; Kervella, Y.; Stephan, O.; Baldeck, P.L.; Andraud, C.; J. Chem. Phys., 2001, 114, 5391-5396; b) Anémian, R.; Morel, Y.; Baldeck, P.L.; Paci, B. Kretsch, K. Nunzi, J.-M.; Andraud, C.; J. Mater. Chem., 2003, 13, 2157-2163; c) Girardot, C.; Lemercier, G.; Andraud, C.; Amari, N.; Baldeck, P.L.; Mol. Cryst. Liq. Cryst., 2005, 426, 197-204.

32 Negres, R.A.; Przhonska, O.V.; Hagan, D.J.; Van Stryland, E.W.; Bondar, M.V.; Slominsky, Y.L.; Kachkowski, A.D., J. Sel. Top. Quant. El., 2001, 7, 849-863.

33 Altomare, A.; Burla, M.C.; Camalli, M.; Carscarano, G.; Giacovazzo, C.; Guagliardi, A.; Moliterni, A.G.G.; Polidori, G.; Spagna, R. J. Applied Crystallography, 1998, 31, 74-77.

34 Sheldrick, G.M. SHELX93. Program for the Refinement of Crystal Structures, 1993, University of Göttigen, Germany.

35 Spek, A.L. PLATON, A Multipurpose Crystallographic Tool, 1998, Utrecht University, Utrecht, The Netherlands.

36 Kovsh, D.I.; Yang, S.; Hagan, D.J.; Van Stryland, E.W. Appl. Opt., 1999, 38, 5168-5180.

37 Gopolan, P.; Katz, H.E. McGee, D.J.; Erben, C.; Zielinsky, T.; Bousquet, D.; Muller, D.; Grazul, J.; Olsson, Y. J. Am. Chem. Soc., 2004, 126, 1741-1747. 
Near IR Nonlinear Absorbing Chromophores with Optical Limiting Properties at Telecommunication Wavelengths

Pierre-Antoine Bouit, Guillaume Wetzel, Gérard Berginc, Brigitte Loiseau, Loïc Toupet, Patrick Feneyrou, Yann Bretonnière, Kenji Kamada, Olivier Maury, Chantal Andraud.
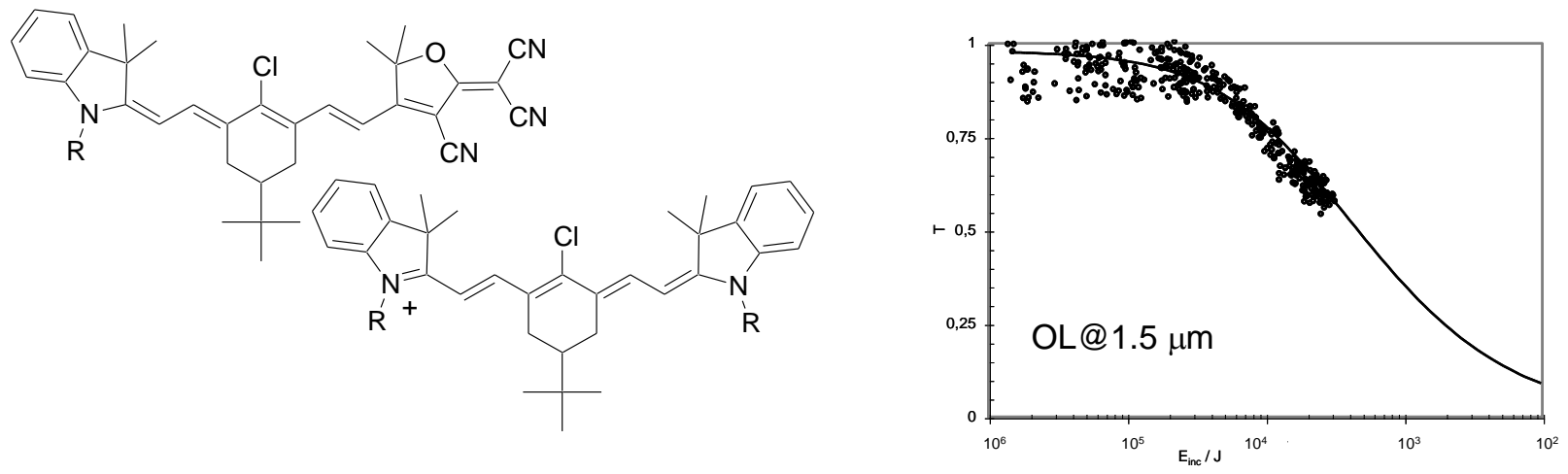

TOC graphic 